\title{
Psychometric Evaluation of Genetic Literacy Instruments in a National Sample
}

\author{
Jamey T. Brumbaugh \\ West Virginia University, jb0251@mix.wvu.edu
}

Follow this and additional works at: https://researchrepository.wvu.edu/etd

Part of the Health Psychology Commons

\section{Recommended Citation}

Brumbaugh, Jamey T., "Psychometric Evaluation of Genetic Literacy Instruments in a National Sample" (2021). Graduate Theses, Dissertations, and Problem Reports. 10306.

https://researchrepository.wvu.edu/etd/10306

This Thesis is protected by copyright and/or related rights. It has been brought to you by the The Research Repository @ WVU with permission from the rights-holder(s). You are free to use this Thesis in any way that is permitted by the copyright and related rights legislation that applies to your use. For other uses you must obtain permission from the rights-holder(s) directly, unless additional rights are indicated by a Creative Commons license in the record and/ or on the work itself. This Thesis has been accepted for inclusion in WVU Graduate Theses, Dissertations, and Problem Reports collection by an authorized administrator of The Research Repository @ WVU. For more information, please contact researchrepository@mail.wvu.edu. 
Psychometric Evaluation of Genetic Literacy Instruments in a National Sample

\author{
Jamey T. Brumbaugh
}
Thesis submitted to the Eberly College of Arts and Sciences
at West Virginia University
in partial fulfillment of the requirements for the degree of
Master of Science in
Psychology

\author{
Daniel W. McNeil, PhD., Chair \\ Mary L. Marazita, $\mathrm{PhD}$ \\ Christa Lilly, $\mathrm{PhD}$ \\ Department of Psychology
}

\author{
Morgantown, West Virginia \\ 2021
}

Keywords: genetic literacy, genetic knowledge, health literacy, psychometrics Copyright 2021 Jamey T. Brumbaugh 


\begin{abstract}
Psychometric Evaluation of Genetic Literacy Instruments in a National Sample
\end{abstract}

Jamey T. Brumbaugh

The concept of genetic literacy continues to grow in clinical and social significance. Whether transforming current healthcare practices or raising questions about genetically-modified foods, genetic information and technologies are primed to further influence people's lives. There is a growing need to understand how genetic literacy is currently assessed in order to inform and improve future test development. This study aimed to investigate the assessment of genetic literacy by psychometrically examining three contemporary genetic literacy instruments (i.e., Genetic Knowledge Survey, International Genetic Literacy and Attitudes Survey (iGLAS-GK), and University of North Carolina Genomic Knowledge Scale (UNC-GKS). Psychometric properties, including internal consistency reliability, reading level, convergent validity (i.e., health literacy and oral health literacy), and discriminant validity (i.e., logical reasoning) were assessed across knowledge tests of genetic literacy in a national USA sample of 809 participants. Results demonstrated each genetic literacy instrument to be positively associated, to a similar degree, with health literacy, oral health literacy, and logical thinking or reasoning capacity. Test difficulty, reading level, and internal reliability varied among the genetic literacy instruments. The study results represent a necessary step toward understanding the measurement of genetic literacy. Such findings and recommendations may inform choice of which genetic literacy scale to use in which circumstances, and the future refinement and development of these assessment tools. 


\section{Table of Contents}

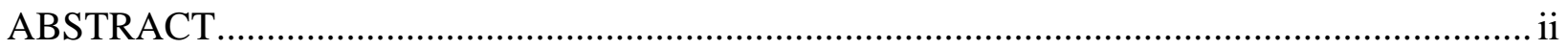

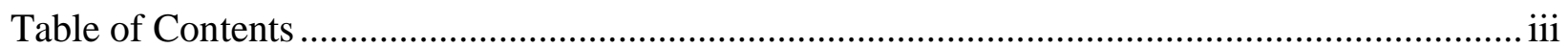

Significance of Studying Genetic Literacy ................................................................. 3

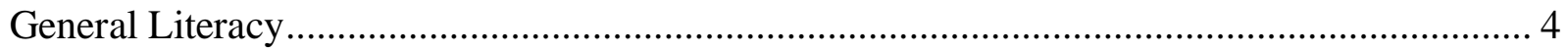

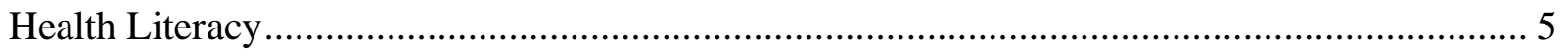

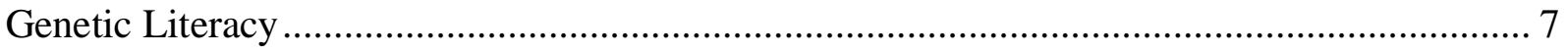

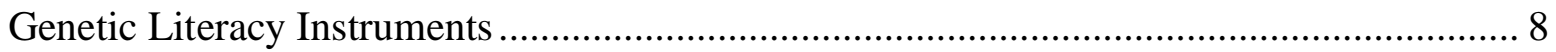

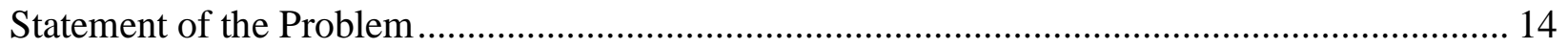

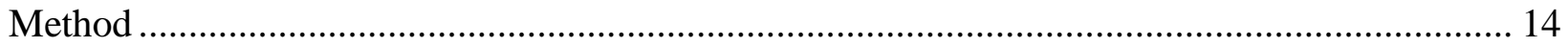

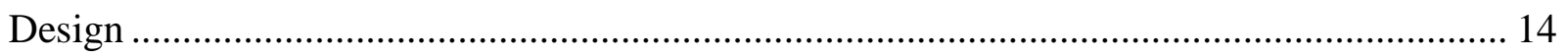

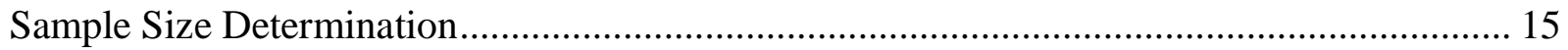

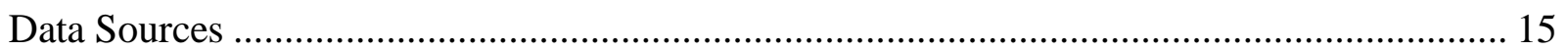

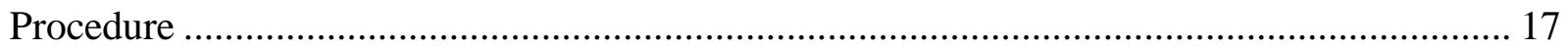

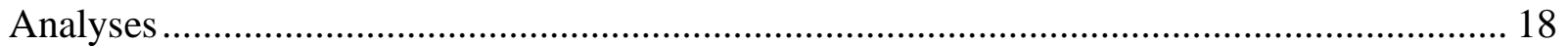

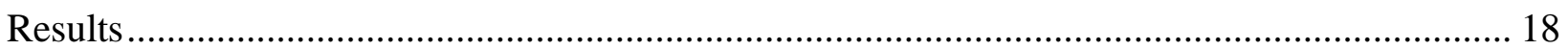

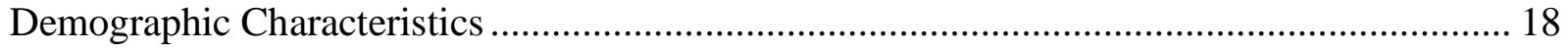

Scale Descriptive Statistics and Psychometrics ........................................................... 19

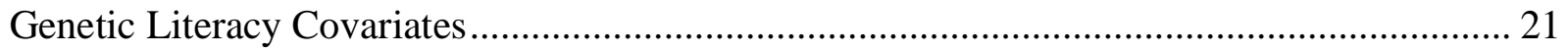

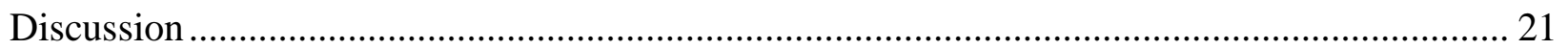

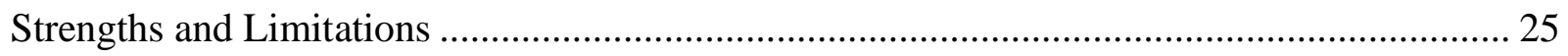

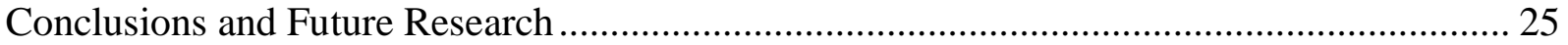




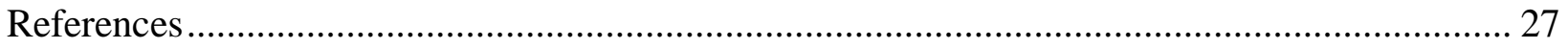

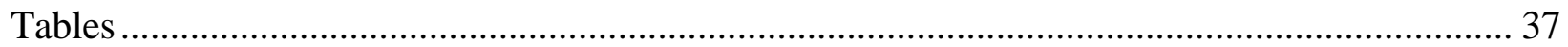

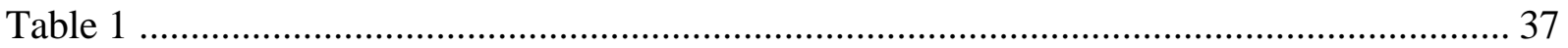

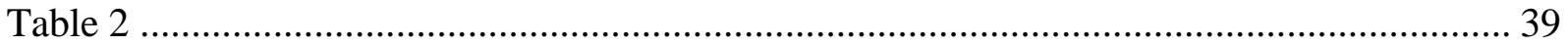

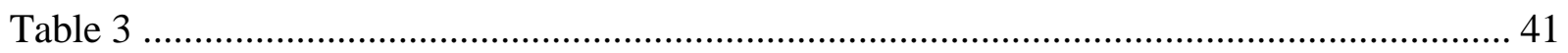

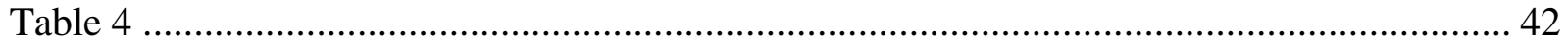

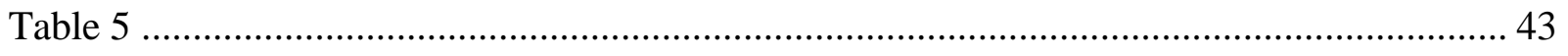

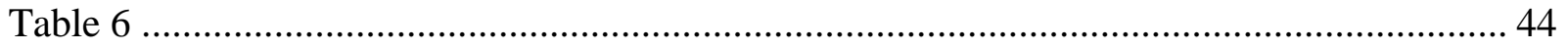

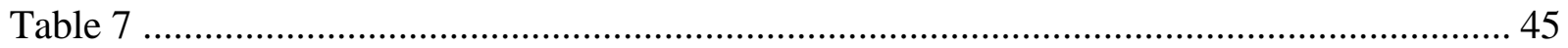

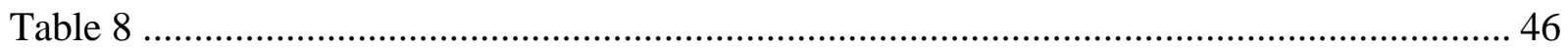

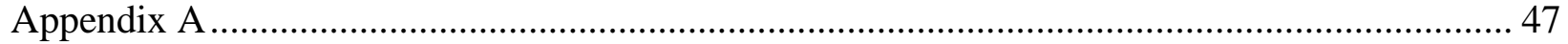

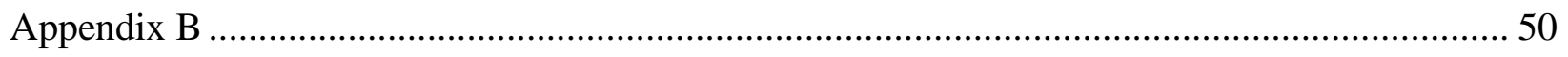

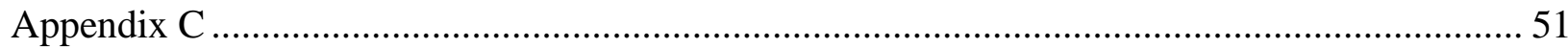

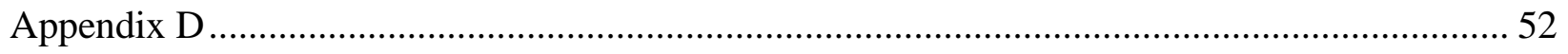

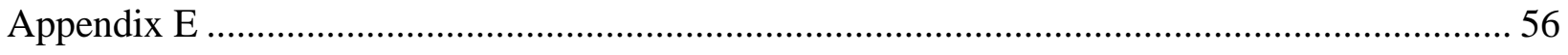

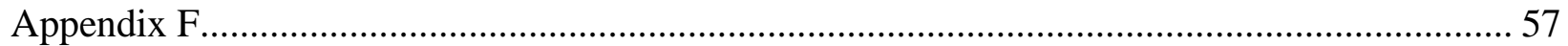

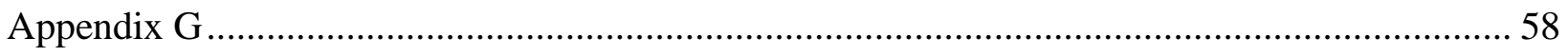




\section{Psychometric Evaluation of Genetic Literacy Instruments in a National Sample}

Health literacy, according to the US Institute of Medicine, is the degree to which individuals have the capacity to obtain, process and understand basic health information and services needed to make appropriate health decisions (Institute of Medicine, 2004). Health decisions and behaviors are performed by people in order to enhance or maintain their health, which includes physical, mental, and social well-being (World Health Organization, 1948). Health literacy provides one with the knowledge to make health-promoting decisions and perform health-promoting behaviors (Nutbeam, 1998). Higher capacities to access and comprehend health information, such as that often contained in medical education brochures, enable a more complete understanding of what types of behaviors promote health. Additionally, the ability to follow the verbal and written advice of healthcare professionals allows one to promote health outside of medical settings. Consequently, deficits in health literacy are associated with lower rates of healthcare utilization and worse health outcomes (Berkman et al., 2011).

Particular types of health literacy have been identified as a means to assess patient literacy within diverse healthcare specializations or domains. Genetic literacy is a subtype of health literacy that may be especially important to assess in genetic counseling or genomic medicine settings. Genetic literacy is defined as having "sufficient knowledge and understanding of genetic principles to make decisions that sustain personal well-being and effective participation in social decisions on genetic issues" (Bowling et al., 2008). Interest in the concept of genetic literacy, as differentiated from health literacy, has increased in recent years (Abrams et al., 2015; LePoire et al., 2019), partially due to advances in genetic technologies. These innovative tools allow for the analysis of large amounts of genomic data, at decreasing costs, and 
are shaping the future of personalized medicine (Kornman \& Duff, 2012). Thus, as fields of healthcare continue to incorporate genetic technologies and information in their domains, interest in the construct of genetic literacy should persist and grow. Additionally, direct-to-consumer (DTC) genetic testing companies are making medically relevant genetic information more available to the public (Hogarth et al., 2008). As the costs of genetic sequencing continue to decrease, DTC companies will be able to offer affordable genetic testing to broader populations, including those with lower socioeconomic status, educational attainment, and genetic literacy (Lachance et al., 2010). Such populations may be more vulnerable to being misled or misguided by the genetic information offered by DTC genetic testing, thereby possibly leading to public mistrust of formal medical genetic testing (Rafiq et al., 2015). Understanding genetic literacy within the context of diverse populations, combined with examining how DTC companies distribute genetic information, is critical to ensuring the responsible dissemination of genetic information to individuals.

As the concept of genetic literacy continues to evolve and grow in importance, it is essential to first understand how genetic literacy is assessed. The measurement of genetic literacy has meaningful clinical and social implications. Clinically, the valid and reliable assessment of genetic literacy is necessary in order to examine its relation to patient acceptance and utilization of genetically related healthcare services, such as genomic medicine or genetic counseling services, as well as patient decision-making. Additionally, accurate measurement of genetic literacy could help improve informed consent protocols used by researchers who collect and analyze human genetic information. Socially, the assessment of genetic literacy is needed to study its relation to social policy decisions that concern genetic information and technologies. 
Thus, understanding how, and to what degree, current assessment instruments capture the construct of genetic literacy is important clinically, scientifically, and socially.

\section{Significance of Studying Genetic Literacy}

Genetic technologies are transforming healthcare. Genetic information, through genetic testing, is increasingly available within healthcare settings to inform clinical assessment and treatment plans (Stark et al., 2019). To give one example, an oncologist may utilize the genetic information of their patients to assess the types of drugs that are likely to be effective in treating their patients' cancer. Such information will directly impact an oncologist's treatment plan for that specific patient. Additionally, genetic technologies and information may play a critical disease risk assessment role. Probabilistic approximations of an individual's susceptibility to certain heritable diseases can estimated through polygenic risk scores (Lambert et al., 2019). Such risk assessment has already displayed clinical utility for major diseases such as Alzheimer's disease, breast and prostate cancer, and type 2 diabetes (Torkamani et al., 2018).

Outside of traditional healthcare settings, genetic information relating to one's health is becoming more ubiquitous. DTC genetic sequencing services, such as 23 and Me and AncestryDNA, have developed to fill the demand of a growing number of people wanting to discover their genetic profiles (Hogarth et al., 2008). Further, most customers of DTC genetic companies are drawn to the medically-relevant genetic information that the services offer (Roberts et al., 2017). As the amount of genetic information patients are exposed to continues to rise, both inside and outside of healthcare settings, it is important to study the capacity at which individuals are capable of interpreting such information through the concept of genetic literacy.

Besides its significance in healthcare, the study of genetic literacy has become a critical social imperative. Public concerns over the use of genetically-modified foods has sparked 
political action in which the USDA established guidelines to label and identify "GMO-free" food products (Jalonick, 2015). Commercial companies that sell, for example, skin-care products, have claimed to utilize the power of genetic technologies to make their products more effective (Geddes, 2014). Understanding how the public interprets genetic information from citizen and consumer standpoints is critical to many major sociopolitical decisions. Whether choosing to label GMO-free food or regulating advertisements that claim genetically-enhanced skin-care products, genetically-related social decisions will need to be made. Moreover, it is likely that public opinions and beliefs may be influenced by knowledge and understanding of genetics. Therefore, influential political decisions relating to genetics, made by those in positions of power, may largely depend on how, and to what degree, the public understands geneticallyrelated concepts.

\section{General Literacy}

Genetic literacy can be thought of as a subtype of health literacy, yet both genetic and health literacy are concepts that are based on the broader construct of general literacy. Literacy has been expressed as "using printed or written information to function in society, to achieve one's goals, and to develop one's knowledge and potential"' (Kutner et al., 2007). Literacy rates from countries across the globe, including from the USA, Argentina, Australia, Japan and others, are often reported as just under 100 percent (Roser \& Ortiz-Ospina, 2016). These literacy rates, however, could likely be overestimated because they generally rely on simplistic definitions of literacy, such as the capacity to read and write in any language (Carr-Hill \& Pessoa, 2008). Additionally, such literacy rates are often derived from country-based census data that use a selfreport format (Carr-Hill \& Pessoa, 2008). 
In efforts to more comprehensively assess literacy, objective tests aimed at measuring a multidimensional construct of literacy were developed by social scientists across multiple nations, including the USA. The National Assessment of Adult Literacy (NAAL) is an examination of general English literacy which was last administered to over 19,000 Americans in 2003 (Kutner et al., 2007). The NAAL assessed three major dimensions of literacy: prose literacy, document literacy, and quantitative literacy. Thus, developers of the NAAL considered literacy to be the knowledge and skills needed to perform prose tasks (e.g., understanding newspapers and instructional materials), document tasks (e.g., comprehending job applications, maps, and food labels), and quantitative tasks (e.g., the capacity to balance a checkbook and calculate a tip at a restaurant) (Kutner et al., 2007). Based on data from the 2003 NAAL, 14 percent of Americans have not acquired the skills necessary to understand simple and everyday prose (Kutner et al., 2007). Additionally, approximately 3 percent of Americans were categorized as being nonliterate, or unable to complete any literary task (Kutner et al., 2007). Low general literacy capabilities can directly impact an individual's ability to develop downstream competencies, including health literacy.

\section{Health Literacy}

Given that health literacy is related to genetic literacy (Kaphingst et al., 2016), genetic literacy instruments have been influenced by approaches to measuring health literacy. Therefore, understanding the approaches to measuring health literacy is central to understanding how genetic literacy is assessed.

Health literacy instruments include knowledge tests, pronunciation tests, and selfassessments. Major knowledge tests of health literacy include the Test of Functional Health Literacy in Adults (TOFHLA, or the shortened S-TOFHLA; Baker et al., 1999) and the more 
contemporary Newest Vital Sign (NVS; Weiss et al., 2005). The TOFHLA is composed of 17 numeracy items and three medically related scenarios in which respondents fill in blanks with certain choices provided. Scores on the TOFHLA have been strongly correlated with scores on another health literacy instrument, the Rapid Estimate of Adult Literacy (REALM). The NVS consists of questions regarding health-related information which are verbally and freely responded to by the test-takers. The NVS relies on a test administrator and is not a selfassessment. Scores on the NVS have been strongly correlated with the Wide Range Achievement Test (WRAT; Wilkinson \& Robertson, 2006) as a general literacy measure, and the TOFHLA. The REALM is a pronunciation test of health literacy that assesses patient ability to accurately pronounce common medical terminology (Davis et al., 1991). Administration of the REALM requires individuals to read aloud each health-related word in order to assess for correct pronunciation. Scores on the REALM have been strongly correlated with the WRAT and the Peabody Individual Achievement Test (PIAT; Davis et al., 1991), which is an assessment of academic or scholastic achievement.

Newer instruments, such as the Health Literacy Questionnaire (HLQ; Osborne et al., 2013) and the All Aspects of Health Literacy Scale (AAHLS; Chinn, \& McCarthy, 2013), take a self-assessment approach to measuring health literacy. The HLQ is composed of 44 items spanning over nine distinct scales that each measure a different dimension of health literacy, including "having sufficient knowledge to manage my health" and "actively managing my health." Each scale on the HLQ is independently evaluated, thus an overall score on the HLQ is not calculated. Every item is assessed on an agree or disagree scale, or on a 4-point level of difficulty scale. The AAHLS is made up of 14 questions that incorporate functional, communicative, and critical health literacy. Scaling and scoring of items for the AAHLS were 
not indicated in the validation study of the AAHLS. Additionally, performance on the AAHLS has not been compared to other health literacy measures.

\section{Genetic Literacy}

Many of the existing genetic literacy measures and instruments have been developed to focus on particular diseases (Richman et al., 2011) or single gene mutations (Green et al., 2001). Additionally, a majority of genetic literacy or knowledge measures were created for single studies (Adams et al., 2014; Scuffham et al., 2014). Recently, instruments have been developed to capture broader conceptualizations of genetic literacy, perhaps in response to calls for the systematic assessment of genetic literacy (Carere et al., 2016). These instruments, along with previously established measures, are detailed below.

Like health literacy instruments, three types of assessments have been developed to measure genetic literacy: knowledge tests, pronunciation tests, and self-assessment measures. The majority of genetic literacy assessments are knowledge tests, specifically knowledge tests that utilize a true or false format. Knowledge assessments are often self-administered, making them useful in busy clinical settings. Additionally, these tests can incorporate items that assess different types of knowledge that each contribute to the overall construct being measured. The major disadvantage of knowledge measures is their vulnerability to validity and reliability issues. Knowledge instruments with items that assess varying types of knowledge often lack strong internal consistency. Some knowledge tests may also be prone to reliability and validity issues given their test format. For example, multiple-choice questions and true or false statements are vulnerable to correct guessing that potentially influences a test's reliability and discriminant validity. A few genetic literacy tests (and two of them are described below) address this issue by adding a "not sure" or "I don't know" response choice to their true or false test formats. Such 
modifications allow true or false assessments to account for a level of uncertainty within their respondents, while also limiting respondent guessing.

Like knowledge tests, pronunciation tests and self-assessment measures have strengths and limitations. Advantages of pronunciation tests include that they are often quick, reliable and not vulnerable to correct guessing like knowledge tests are. The central disadvantage of pronunciation tests, however, is their presumption that word articulation directly translates into comprehension of the concept that the word represents. Thus, it is crucial to study the validity of pronunciation tests by examining their associations with related comprehension or knowledge tests. For example, the REALM, mentioned above, is strongly correlated with achievementorientated health literacy tests. Another disadvantage is that natural differences in respondent and test administrator dialects or pronunciation styles may lead to unreliable scoring, or even the unfair scoring of respondents with diverse inflections. For example, a mismatch between the first language of the administrator and respondent may negatively impact the assessment of accuracy of pronunciation. Such mismatches that are likely to arise with pronunciation-based tests potentially impair or bias administrator objectivity, increasing a threat of discrimination based on respondent sociocultural factors. Lastly, self-assessment measures are useful when researchers or clinicians are interested in studying an individual's perceived degree of, for example, genetic literacy. The disadvantage of self-assessments, however, is that perceived aptitude and actual aptitude, for a given psychological capacity, often vary in degree. Taken together, the disadvantages of pronunciation tests and self-assessment measures explain why a majority of genetic literacy assessments are knowledge tests.

\section{Genetic Literacy Instruments}


Knowledge of Genes and Heredity Measure (KGHM). This knowledge assessment is an older instrument developed to measure genetic literacy and was based on a representative sample of 1,216 Finnish citizens (Jallinoja \& Aro, 1999). This test is made up of 16 true or false items based on knowledge about genes and diseases and genes in relation to cell biology. Each correct statement identified as true or false earns the respondent one point. Additionally, the internal consistency value of the KGHM has been estimated to be 0.86 (Cronbach's alpha).

Genetic Knowledge Index (GKI). The GKI is a five-item knowledge test of genetic literacy and was developed to be a unidimensional assessment of foundational knowledge regarding genetics (Furr \& Kelly, 1999). Each of the five items represent statements in which participants mark either true or false. For example, the statement "once a genetic marker for a health condition is found in a person, the condition can be prevented or cured" is evaluated as being true or false. The GKI's validity and reliability estimates were determined based on a random sample of 330 participants from Louisville, KY. The GKI has evidence of internal reliability (Cronbach's alpha $=0.74)$ and convergent validity with educational attainment.

Genetics Literacy Assessment Instrument (GLAI). The GLAI is a 31-item multiplechoice test assessing 17 concepts believed central to the measurement of genetic literacy (Bowling et al., 2008). The GLAI was developed as a means to assess the genetic knowledge of undergraduate students, particularly students from non-biological or non-science majors. Validity and reliability estimates for the GLAI were gathered using a convenience sample of approximately 400 undergraduates from introductory biology courses or non-science majors. A small sample of graduate students in genetics specialties were included in order to examine the discriminant validity of the GLAI. A sample of graduate students scored significantly higher on the GLAI than both samples of undergraduates, whereas no significant difference was found 
between the two undergraduate groups. Additionally, the GLAI yielded a test-retest reliability correlation of 0.68 , with seven weeks between tests, and a Cronbach's alpha of 0.99 .

\section{Rapid Estimate of Adult Literacy in Genetics (REAL-G). The REAL-G is a}

commonly used pronunciation test to assess genetic knowledge (Erby et al., 2008) and is modeled after Rapid Estimate of Adult Literacy in Medicine (REALM; Davis et al., 1991). The REAL-G is a 63-item assessment in which administrators provide participants with a list of genetically-related terms. Such terms are read aloud by the participant and assessed by the administrator for their quality of pronunciation. Concurrent validity, as indicated by significant associations with the REALM $(r=0.83)$, and predictive validity evidence for the REAL-G has been established. A shortened REAL-G of eight items was developed in conjunction with the 63item REAL-G (Erby et al., 2008). Both versions of the REAL-G were psychometrically evaluated on a convenience sample of 203 participants. The shorted version of the REAL-G was found to have similar concurrent and predictive validity.

Genetic Literacy and Comprehension Measure (GLAC). The GLAC was developed as a self-administered written alternative to the REAL-G (Hooker et al., 2014). Using the same eight items or terms from the short version of the REAL-G, participants taking the GLAC rate their general familiarity with each term on a 7-point Likert scale, with 1 representing "not familiar at all" and 7 representing "completely familiar." Genetically related terms, such as “chromosome," "susceptibility," and "mutation" are evaluated for familiarity. After each term is rated for its familiarity, each respondent answers a fill-in-the-blank question relating to that item. Psychometric evaluation of the GLAC was based on a convenience sample of 257 patients from an inflammatory bowel disease clinic. Evidence of internal reliability (Cronbach's alpha $=0.95$ ) was established. 
Genome Sequencing Knowledge Test. This instrument is a test of genome sequencing knowledge made up of two subtests, Sequencing Limitations knowledge and Sequencing Benefits knowledge (Kaphingst et al., 2012). This test is made up of 11 items statements, with a quasi-true/false-like format. Instead of indicating true or false, participants respond to each item through marking their level of agreement with each statement on a 5-point Likert scale, from "strongly agree" to "strongly disagree." This response format was chosen in order to capture the degrees of uncertainty and to dissuade guessing among test takers. Each subtest within this genome sequencing test was evaluated for its degree of internal consistency based on a convenience sample of 311 patients enrolled in a sequencing study. The Cronbach's alpha for the Limitations subscale was 0.80 and 0.70 for the Benefits subscale. Item reading level could be a potential limitation with this genome sequencing knowledge test. Particular words included in multiple items, such as "variant," may cause confusion in its respondents.

Genetic Knowledge Survey. This genetic knowledge test was constructed in order to capture the genetic literacy of adolescents and adults (Fitzgerald-Butt et al., 2016). Derived from the Knowledge of Genes and Heredity Measure (Jallinoja \& Aro, 1999), the Genetic Knowledge Survey consists of 18 true or false statements. Psychometric evaluation of this test was based on a convenience sample of 661 parents and adolescents from a clinical setting. Upon factor analyses, a two-factor structure was determined for this genetic knowledge test, a Basic subscale and an Applied subscale. The Basic subscale (Cronbach's alpha $=0.66$ ) is a measure of knowledge about genes and their relation to cell biology. The Applied subscale (Cronbach's alpha $=0.73)$ is a measure of genes and their relation to genetic testing and disease.

International Genetic Literacy and Attitudes Survey (iGLAS). The iGLAS was developed as an all-encompassing means of assessing genetic literacy and attitudes or beliefs 
towards genetics (Chapman et al., 2017). The iGLAS is made up of four distinct sections or scales: demographics, genetic knowledge, heredity estimates, and opinion about genetics. The iGLAS Genetic Knowledge Scale (iGLAS-GK), is a knowledge measure of genetic literacy. The iGLAS-GK is composed of 20 multiple choice and true or false items. Such questions test basic knowledge related to genetics, genomics, and heredity. A convenience sample of 5,405 online participants was used to psychometrically evaluate the iGLAS and iGLAS-GK. Statistical evaluation of the iGLAS-GK resulted in evidence for a moderate-strong degree of test-retest reliability $(r=0.67)$. Factor analysis revealed that the iGLAS-GK did not represent a unitary construct or concept, such as genetic knowledge.

University of North Carolina Genomic Knowledge Scale (UNC-GKS). The UNCGKS was developed in order to assess genomic knowledge across general clinical domains and differing sociodemographic populations (Langer et al., 2017). The UNC-GKS is a 25-item measure that uses a true or false format that also allows participants to mark "not sure/don't know." A 19-item version of the UNC-GKS was developed and evaluated in conjunction with the full test as a way to access general genomic literacy while excluding content regarding whole-exome sequencing. The UNC-GKS was developed on a sample of 418 participants (286 adult patients, 132 parents of patients) enrolled in the North Carolina Clinical Genomic Evaluation by Next-generation Exome Sequencing study. Psychometric evaluation of the UNCGKS provided evidence of a unitary factor structure, internal reliability (Cronbach's $\alpha=0.90$ ), and convergent validity with other health and genetic related literacy measures. Item reading level for the UNC-GKS should be assessed. Potentially confusing language, such as "variant," may limit the measures ability to capture a respondent's true levels of genomic knowledge. 
Knowledge of Genome Sequencing (KOGS). The KOGS was developed in order to assess whole-genome sequencing specific knowledge (Sanderson et al., 2018). The KOGS is a 9item measure that uses a true or false format that also allows participants to mark "don't know." The KOGS is not intended to be a measure of general genetic or genomic literacy. Instead, the KOGS is an instrument designed to assess a particular component of genetic literacy in the form of knowledge relating to whole-genome sequencing. Psychometric properties for the KOGS were determined using a convenience sample of 267 participants, mostly consisting of university students and staff. Adequate internal consistency estimates for the KOGS (Cronbach's alpha = 0.79) have been reported.

Genetic Literacy Fast Test (GeneLiFT). The GeneLiFT was developed as a selfadministered and rapid test of genetic literacy (Milo Rasouly et al., 2021). The GeneLiFT is a 51-item vocabulary recognition test in which respondents work to differentiate between real and fake genetic terminology. Construct validity for the GeneLiFT was determined through significant associations with measures of genetic knowledge/genetic literacy, health literacy, numeracy, and education on a clinical sample of 724 patients who have undergone genetic screening for a variety of gene variants. No information regarding reliability was included in the GeneLiFT validation study.

The genetic literacy instruments outlined and described above represent validated assessments of general genetic literacy or knowledge. Each genetic literacy instrument can be categorized as a knowledge-based, pronunciation-based, or word/vocabulary recognition-based assessment. Though pronunciation-based assessments (e.g., REAL-G) are commonly used, the present study focuses on knowledge-based genetic literacy instruments due to the sociocultural limitations of pronunciation-based assessment already described. Contemporary and up-to-date 
knowledge-based tests of genetic literacy (i.e., Genetic Knowledge Survey, iGLAS-GK, and UNC-GKS) were examined.

\section{Statement of the Problem}

The examination of genetic literacy instruments to date has revealed two major gaps in the literature. One issue is that the vast majority of genetic literacy measures are psychometrically evaluated based on convenience clinical samples. Such samples are vulnerable to selection bias and homogeneity. Psychometric qualities of genetic literacy instruments based on these samples may be limited in their ability to generalize to broader populations. A second issue relates to a lack of comparative psychometric studies. No study has yet to examine the psychometric properties of multiple genetic literacy instruments utilizing one sample.

Additionally, it is apparent that several knowledge tests of genetic literacy incorporate items with complex language, yet no research exists that examines the reading level of these instruments and their test items. Based on these issues, there is a need to independently evaluate the most contemporary and relevant knowledge tests of genetic literacy in terms of their reliability and validity using a national USA sample.

\section{Research Question}

What are the psychometric strengths and weaknesses of select contemporary genetic literacy instruments in terms of internal consistency reliability, convergent and discriminant validity, and readability?

\section{Method}

\section{Design}

The study used a cross-sectional design to examine the psychometric properties of three contemporary genetic literacy instruments. These instruments were assessed in regard to their internal consistency reliability, convergent validity, discriminant validity, and reading level. A 
multitrait-multimethod matrix (MTMM) approach (Campbell \& Fiske, 1959) was utilized to evaluate the various genetic knowledge tests.

\section{Sample Size Determination}

The proposed sample size was determined through the use of the power analysis program G*Power 3 (Faul et al., 2007). Pearson's correlation coefficients was calculated between the genetic literacy instruments and other criterion variables (i.e., health literacy, oral health literacy and logical thinking) in order to assess convergent and discriminant validity. The alpha level for the proposed analyses was set at 0.05 and the power was set to 0.95 . Based on the previous validation study, genetic literacy scores are moderately associated health literacy and geneticallyrelated health literacy (Langer et al., 2017). Given the proposed analysis, and assuming a small effect size of $r=0.15$ in order to be conservative, a sample of 571 participants was needed.

\section{Data Sources}

Data from a national adult USA sample was obtained from Amazon's Mechanical Turk (MTurk), which is a popular online data collection service that allows for large samples to be obtained in an efficient and relatively inexpensive manner (Buhrmester et al., 2011). MTurk allows for the ability to recruit participants from various international or national regions (Cheung et al., 2017). There is evidence to support that experiments conducted on platforms such as MTurk can be as externally and internally valid as field experiments (Cheung et al., 2017). Though participants recruited on MTurk may over-represent specific groups from the USA population (e.g., young and politically liberal), such samples have been found to be more diverse than traditional undergraduate ones (Buhrmester et al., 2011). Specific MTurk sampling practices outlined in Litman et al. (2020) (i.e., excluding highly active workers and sampling across multiple days/times of day) were incorporated in order to maximize sample representativeness.

\section{Measures}


Genetic Literacy. The psychometric properties of the International Genetic Literacy and Attitudes Survey-Genetic Knowledge Scale (iGLAS-GK; Chapman et al., 2017), the University of North Carolina Genomic Knowledge Scale (UNC-GKS; Langer et al., 2017), and the Genetic Knowledge Survey (Fitzgerald-Butt et al., 2016) were examined. These three instruments were selected because they represent the most contemporary and up-to-date measures of general genetic literacy, and are not pronunciation-based literacy examinations. Information regarding each of these instruments is detailed above and summarized in Table 1. Additionally, the iGLASGK can be found in Appendix A, the UNC-GKS in Appendix B, and the Genetic Knowledge Survey in Appendix C.

Health Literacy. Health Literacy was measured by the shortened Test of Functional Health Literacy in Adults (S-TOFHLA; Baker et al., 1999). The S-TOFHLA is an objective assessment of functional health literacy composed of 36 comprehension questions and 4 numeric calculations. Scores on the S-TOFHLA range from 0-100 with greater scores indicating higher levels of functional health literacy. Sample items of the S-TOFHLA can be viewed in Appendix D.

Oral Health Literacy. Oral health literacy was measured by the Health Literacy in Dentistry Scale (HeLD; Jones et al., 2015). The HeLD is a 29-item assessment of oral health literacy. Each item is measured on a 5-point Likert-type scale of "difficulty experienced." Single items are scored from 0-4 and total scores on the HeLD range from 0-116. Higher scores on the HeLD indicate higher levels of oral health literacy. All HeLD items can be viewed in Appendix E.

Logical Thinking. The Test of Logical Thinking (TOLT; Kenneth \& William, 1981) was used to measure formal reasoning or logical thinking. The TOLT is a 10-item multiple-choice 
test of formal logical reasoning abilities. Correct answers are worth 1 point and the range of TOLT scores is from 0-10, with higher scores indicating greater levels of logical thinking ability. This test was included in order to assess a concept (i.e., logical thinking) that should be distantly related genetic literacy. Sample items from the TOLT can be viewed in Appendix F.

Demographics. Sample demographic characteristics were measured through administration of the full International Genetic Literacy and Attitudes Survey (iGLAS; Chapman et al., 2017). Participants reported on gender, age, race/ethnicity, education, genetics-specific education, employment, and other demographic factors. Additional genetically related covariates (i.e., individual or family genetic test history and individual or family known genetic disorder) were assessed.

\section{Procedure}

Participants were recruited and compensated through MTurk for their contribution to the study. All participants were paid one dollar and 50 cents for completion of the study survey. Data collection via MTurk was completed between June 22 to July 27, 2021. Participants completed all demographic measures, three genetic literacy instruments, health and oral health literacy measures, and a test of logical thinking through a Qualtrics survey (Qualtrics, Provo, UT). Genetic literacy, health literacy, oral health literacy, and logical thinking tests were randomly administered to each participant in order to control for fatigue effects. Demographic questions were completed after all other survey measures. A "request response" format was used for each survey item, which alerted participants when there was not a response to a particular item. The participant could choose an alternative to not respond. Participants were excluded from analyses for failing to complete the study survey (i.e., not completing greater than $20 \%$ of survey responses; $n=775$ ), taking too much or too little time to complete the survey (i.e., $<-3.3$ or $>3.3$ SD's from completion duration mean; $n=1$ ), or responding incorrectly to any of the four 
validity items ( $n=14$; See Appendix G for validity items). After removal of excluded participants, no study variable was found to be missing at a significant rate (i.e., > 1\%).

Additionally, no scale or instrument items were found to be missing any responses. The average survey completion duration was 42 minutes $(S D=22$ minutes).

\section{Analyses}

The psychometric properties of all three genetic literacy instruments were evaluated based on a national adult sample. First, each measure's reading grade level and reading ease level were assessed by applying the Flesch-Kincaid readability formula (i.e., grade level and readability; Flesch, 1948), which was accessed on Microsoft Word ${ }^{\mathrm{TM}}$. Next, internal consistency reliability was examined with Cronbach's alpha for each genetic literacy measure. Lastly, construct validity for the genetic literacy instruments was investigated by generating a simplified MTMM matrix. In this matrix, three measured traits: (a) health literacy (measured by the STOFHLA), (b) oral health literacy (measured by the HeLD), and (c) logical thinking (measured by the TOLT) were correlated to three genetic literacy methods: (a) iGLAS-GK, (b) UNC-GKS, and (c) the Genetic Knowledge Survey. Pearson correlations between traits and methods were used as data informing genetic literacy instrument convergent and discriminant validity (i.e., construct validity). Additionally, Pearson correlations between the S-TOFHLA, HeLD, and TOLT were generated in order to examine how health literacy and oral health literacy relate to logical thinking.

\section{Results}

\section{Demographic Characteristics}

The final sample included 809 participants from the USA with different sociodemographic identities (See Table 2) and a variety of experiences to genetics and genetic testing, as shown in Table 3 . The mean age of participants was approximately 43 years $(M=$ 
42.5; $S D=14.2$; range: $19-83)$. The study sample included $545(67.5 \%)$ females, $252(31.2 \%)$ males, and $11(1.4 \%)$ participants with gender identities outside of the male-female binary distinction. Most participants reported at least some college education experience $(84.1 \%)$ and the median annual household income bracket was $\$ 50,000-\$ 74,999$. A majority of the sample racially identified as White $(81.5 \%)$. Other racial identities representing over one percent of the sample included Black or African American (9.1\%), Asian American (3.5\%), multiracial identities (1.6\%), and participants with racial identities other than the categories presented (2.6\%). Additionally, 60 participants (7.4\%) indicated having a Hispanic ethnic background. Based on the USA census data of 2020, the study sample overrepresented those identifying as female and participants with White racial identities. Participants with Hispanic ethnic origins were the sociodemographic group least represented when compared to national statistics, as this group makes up $18.5 \%$ of the USA population.

Over one quarter $(32.9 \%)$ of participants indicated studying genetic-related topics as part of a school curriculum, whereas $49.3 \%$ reported never studying genetics. In terms of genetic diagnoses, $11.4 \%(n=92)$ of participants indicated having a genetic disorder themselves and $20.3 \%(n=164)$ reported having a family member with a genetic disorder. Almost one quarter $(23.3 \% ; n=184)$ of participants indicated receiving prior genetic testing, with most $(78.3 \%)$ reporting genetic testing for ancestry, heritage, or genealogical information, as opposed to medical diagnosis or risk of disorder testing (34.2\%). Even more $(34.8 \% ; n=238)$ participants indicated knowing a family member who received a previous genetic test, mostly for ancestry, heritage, or genealogy information $(83.6 \%)$.

\section{Scale Descriptive Statistics and Psychometrics}


Descriptive results for the three genetic literacy instruments and all other study scales can be found in Table 4. A mean percentage correct score of $77.2 \%$ was tabulated for the Genetic Knowledge Survey, $70.1 \%$ for the UNC-GKS, and $60.4 \%$ for the iGLAS-GK. Mean percentage correct was significantly different between the Genetic Knowledge Survey and the UNC-GKS $[F(19,789)=63.6, p<0.001]$, the Genetic Knowledge Survey and the iGLAS $[F(16,792)=$ 14.0, $p<0.001]$, and the UNC-GKS and the iGLAS $[F(19,789)=16.7, p<0.001]$. Item-level rate of correct responses and "I don't know" responses are included in Table 5 and 6 for the Genetic Knowledge Survey and UNC-GKS, respectively. Additionally, Table 7 includes itemlevel rate of correct responses for the iGLAS-GK. The Genetic Knowledge Survey had one item with a correct response rate less than $50 \%$ and a mean "I don't know" response rate per item of 14.1\%. The UNC-GKS had two items with a correct response rate less than $50 \%$ and a mean "I don't know" response rate per item of 19.2\%. Lastly, the iGLAS-GK had 6 items with a correct response rate less than $50 \%$.

Psychometric properties, including internal consistency reliability and reading level, are also reported in Table 4. The Genetic Knowledge Survey was found to have a Cronbach's alpha of 0.82, a Flesch-Kincaid grade level of 7.0, and a Flesch Reading Ease of 61.3. The UNC-GKS was found to have a Cronbach's alpha of 0.83 , a Flesch-Kincaid grade level of 8.6, and a Flesch Reading Ease of 57.2. The iGLAS-GK was found to have a Cronbach's alpha of 0.67, a FleschKincaid grade level of 6.5, and a Flesch Reading Ease of 66.8. The Cronbach's alpha for each genetic literacy instrument was also determined using only participants who indicated having a genetic disorder diagnosis or having a family member with a genetic disorder diagnosis. A Cronbach's alpha of 0.80 for the Genetic Knowledge Survey, 0.82 for the UNC-GKS, and 0.72 for the iGLAS-GK was determined based on this subgroup of 181 individuals. 
Pearson correlations among all study instruments are presented in Table 8 . The Genetic Knowledge Survey was significantly associated with the UNC-GKS $(r=0.76, p<0.01)$ and the iGLAS-GK $(r=0.49, p<0.01)$. The UNC-GKS was significantly associated with the iGLASGK $(r=0.48, p<0.01)$. The Genetic Knowledge Survey was significantly associated with the STOFHLA $(r=0.33, p<0.01), \operatorname{HeLD}(r=0.19, p<0.01)$, and TOLT $(r=0.44, p<0.01)$. The UNC-GKS was significantly associated with the S-TOFHLA $(r=0.29, p<0.01)$, HeLD $(r=$ $0.16, p<0.01)$, and TOLT $(r=0.44, p<0.01)$. The iGLAS-GK was significantly associated with the S-TOFHLA $(r=0.31, p<0.01), \operatorname{HeLD}(r=0.16, p<0.01)$, and TOLT $(r=0.49, p<$ 0.01). The S-TOFHLA was significantly associated with the HeLD $(r=0.38, p<0.01)$. Lastly, the TOLT was significantly associated with the S-TOFHLA $(r=0.27, p<0.01)$ and HeLD $(r=$ $0.13, p<0.01)$

\section{Genetic Literacy Covariates}

Age was significantly associated with the Genetic Knowledge Survey $(r=0.17, p<0.01)$ and the UNC-GKS $(r=0.10, p<0.01)$. No significant relation between age and the iGLAS-GK was found. Gender was not found to be significantly associated with any of the three genetic literacy instruments. Self-reported genetic knowledge was significantly but weakly associated with the Genetic Knowledge Survey $(r=0.17, p<0.01)$, the UNC-GKS $(r=0.21, p<0.01)$, and the iGLAS-GK $(r=0.24, p<0.01)$. Participants with prior personal genetic testing experience $(n=184)$ had significantly greater genetic literacy scores in terms of the Genetic Knowledge Survey $(t(789)=5.75, p<.001)$, the UNC-GKS $(t(789)=6.54, p<.001$, and the iGLAS-GK $(t(789)=5.99, p<.001)$ than those who did not $(n=607)$.

\section{Discussion}


This research is unique in that it involved the examination of the psychometric properties of three contemporary genetic literacy instruments across the same sample. Participants varied in percent of correct responses among the genetic literacy instruments. Test format (i.e., correct/incorrect/I don't know vs. multiple choice) may help explain why the Genetic Knowledge Scale and the UNC-GKS were less difficult tests than the iGLAS-GK. Compared to the Genetic Knowledge Scale, the UNC-GKS was a more difficult test, as evidenced by lower total percentage correct and higher rates of "I don't know" responses. The difference in difficulty between the UNC-GKS and the Genetic Knowledge Survey may be explained by the UNCGKS's increased reading grade level (greater than $8^{\text {th }}$ grade) and problematic reading ease level (less than 60). These results highlight how individuals and groups will vary in their degree of genetic literacy depending on which measure of genetic literacy is chosen in a given study. It is therefore critical for researchers to understand the difficulty of each aforementioned genetic literacy instrument before making claims regarding sample genetic literacy aptitude.

The psychometric properties of the UNC-GKS were similar compared to its original validation study. Langer et al. (2017) reported a Cronbach's alpha of 0.86 for the UNC-GKS; the present study had a similar Cronbach's alpha of 0.83 for the UNC-GKS. Like the present results, Langer et al. (2017) found that UNC-GKS scores were moderately associated with other genetic literacy and health literacy constructs. Present results found the Genetic Knowledge Survey to have a greater Cronbach's alpha (0.82) than the two Cronbach's alpha scores reported by Fitzgerald-Butt et al. (2016) for the either instrument subscale (i.e., Basic subscale =0.66; Applied subscale $=0.73$ ), indicating that the Genetic Knowledge Survey should be utilized as a unitary measure of genetic literacy. Similar to Chapman et al., (2017), the present results found the iGLAS to inadequate internal consistency reliability (Cronbach's alpha $=0.67$ ). 
Associations with convergent validity constructs (i.e., health literacy and oral health literacy) were similar across each genetic literacy instrument. As expected, health literacy was associated with genetic literacy to a higher degree than oral health literacy. Such results provide evidence of similar degrees of convergent validity among the genetic literacy instruments. Additionally, the results indicate that genetic literacy may be more closely related to general health literacy than subtypes of health literacy which are commonly broken down by health specialty. Genetic literacy, therefore, may be thought to be similar to general health literacy in that the construct could impact patient outcomes across all healthcare settings. Evidence of genetic risk information growing across various healthcare domains (Torkamani et al., 2018) further emphasizes the universal significance of genetic literacy.

Associations with the discriminant validity construct (i.e., logical thinking), were similar across each genetic literacy instrument. Moderate associations between genetic literacy and capacity for logical thinking underscores a potential shortcoming of these genetic literacy instruments. It should be expected for logical thinking ability to have a small association with genetic literacy, similar to logical thinking's association with health literacy and oral health literacy. For example, it is reasonable to assume that some capacity for logical thinking or reasoning is related to test-taking ability. Each genetic literacy measure, however, was found to have greater associations with logical thinking compared to health and oral health literacy measures. These results may point to a major limitation of the genetic literacy instruments examined. It is possible that the genetic literacy instruments are constructed in a complex, demanding, or even unfair manner that require increased levels of logical reasoning power to achieve higher scores. Reading level analyses, however, found only the UNC-GKS to have a potentially problematic reading grade level and reading ease level. An alternate explanation, 
therefore, may implicate the concept of genetic literacy, instead of implicating the specific genetic literacy instruments. That is, the content contributing to the construct of genetic literacy may require higher logical thinking capacity beyond what is needed for health and oral health literacy.

The proportion of participants reporting to have a genetic disorder diagnosis, or a family member with a genetic disorder diagnosis, may highlight a fundamental misunderstanding regarding genetic disorder conceptualization held by the public. Genetic disorders, warranting a potential genetic diagnosis, are currently categorized by single-gene disorders and chromosomal disorders. To date, over 6000 single-gene (i.e., monogenic; often referred as "Mendelian diseases") disorders (e.g., cystic fibrosis and Rett Syndrome) have been characterized (Jackson et al., 2018), affecting less than five percent of the population worldwide (Chakravarti, 2011). More rare are chromosomal disorders (e.g., Down Syndrome), which have been estimated to affect less than one percent of births, with rates increasing by maternal age (Zhang et al., 2017). Given actual prevalence estimations of diagnosable genetic disorders, it is improbable that the $11.4 \%$ of sample respondents have a genetic disorder, even if subjects were more likely to participate in this study because they have a genetic disorder. The likely mismatch between reported respondent genetic diagnosis and actual genetic disorder prevalence could indicate that participants misunderstand the difference between a genetic disorder and a genetic risk for a disorder. That is, a number of respondents may have reported having a genetic diagnosis based solely on receiving probabilistic health-related genetic information, rather than a concrete genetic diagnosis that can be determined in monogenic and chromosomal conditions. Potential misunderstandings of this magnitude further highlight the role and significance of genetic literacy. 


\section{Strengths and Limitations}

The present study has noteworthy strengths, including its utilization of a single sample to compare the psychometric properties across three contemporary genetic literacy instruments. This is in stark contrast with the genetic literacy literature where individual instruments are typically validated on an isolated sample, thus limiting ability to compare psychometrics across measures. Additionally, the present study used a sampling method that allowed for individuals across the USA to volunteer for this study. Prior work that has primarily used clinical samples may not accurately represent public genetic literacy aptitude due to already having experiences with genetic testing in healthcare. A national sample in the present study, therefore, may more accurately represent the genetic literacy rates of the public.

As with any study, the present study has several limitations. First, study sample characteristics did not closely represent current USA demographics. Though the sample embodied a variety of sociocultural backgrounds, the study overrepresented female participants and participants with White racial identities. Given sample demographics, the study findings may not generalize to underrepresented racial/ethnic groups, particularly groups of Hispanic origin. Another limitation of the study was that it was not able to test any pronunciation-based assessment of genetic literacy. Due to electronic survey administration, the present study was only able to examine the psychometric properties of knowledge-based genetic literacy instruments, and self-reported assessment of genetic knowledge. Interestingly, the relation between these self-ratings and each of the three knowledge tests was quite weak. The inherent limitations in pronunciation tests and self-assessments of genetic knowledge should be further clarified.

\section{Conclusions and Future Research}


Genetic literacy research, in terms of the measurement of the construct, is in the early stages. This study highlighted psychometric strengths and weakness among three contemporary knowledge tests of genetic literacy, some of which are shared and others which are unique to a specific instrument. Strengths, including evidence of convergent validity for all measures and adequate internal reliability for two measures (i.e., Genetic Knowledge Survey and UNC-GKS), mark an important functionality among the instruments. Weaknesses, including moderate associations with logical thinking or reasoning, highlight a significant need for future scale refinement. Current knowledge tests of genetic literacy, however, are better philosophically and practically than pronunciation assessments, which risk sociocultural bias and discrimination. A recent measure of genetic literacy, GeneLiFT (Milo Rasouly et al., 2021), uses a vocabulary recognition format, which may suffer from a similar limitation common to pronunciation-based assessments (i.e., mismatch between word recognition and concept comprehension). It is therefore recommended that future research focus on adapting and developing knowledge or comprehension assessments of genetic literacy. Scale refinement and development may be informed by work that has identified critical conceptual knowledge, sociocultural, and epistemically components underlying genetic literacy (Boerwinkel et al., 2017). Such work has emphasized the role of understanding certainty and uncertainty as important to genetic literacy. In relation to the present study, certainty and uncertainly regarding whether one has, or does not have, a genetic disorder may occupy a new content space for future scale development. As genetic testing transformation is here and growing exponentially, working toward appropriate measures of genetic literacy is a necessary step to ensure that all people and groups have the ability to successfully navigate this new and evolving healthcare terrain. 


\section{References}

Abrams, L. R., McBride, C. M., Hooker, G. W., Cappella, J. N., \& Koehly, L. M. (2015). The many facets of genetic literacy: Assessing the scalability of multiple measures for broad use in survey research. PloS One, 10(10). https://doi.org/10.1371/journal.pone.0141532

Adams, H. R., Rose, K., Augustine, E. F., Kwon, J. M., deBlieck, E. A., Marshall, F. J., Vierhile, A., Mink, J. W., \& Nance, M. A. (2014). Experience, knowledge, and opinions about childhood genetic testing in Batten disease. Molecular Genetics and Metabolism, 111(2), 197-202. https://doi.org/10.1016/j.ymgme.2013.10.017

Altin, S. V., Finke, I., Kautz-Freimuth, S., \& Stock, S. (2014). The evolution of health literacy assessment tools: A systematic review. BMC Public Health, 14(1), 1207. https://doi.org/10.1186/1471-2458-14-1207

Ashida, S., Goodman, M., Pandya, C., Koehly, L. M., Lachance, C., Stafford, J., \& Kaphingst, K. A. (2011). Age differences in genetic knowledge, health literacy and causal beliefs for health conditions. Public Health Genomics, 14(4-5), 307-316.

https://doi.org/10.1159/000316234

Arozullah, A. M., Yarnold, P. R., Bennett, C. L., Soltysik, R. C., Wolf, M. S., Ferreira, R. M., Lee, S. D., Costello, S., Shakir, A., Denwood, C., Bryant, F. B., Davis, T. (2007). Development and validation of a short-form, Rapid Estimate of Adult Literacy in Medicine. Medical Care, 45(11), 1026-1033. https://www.jstor.org/stable/40221577

Baker, D. W., Williams, M. V., Parker, R. M., Gazmararian, J. A., \& Nurss, J. (1999). Development of a brief test to measure functional health literacy. Patient Education and Counseling, 38(1), 33-42. https://doi.org/10.1016/S0738-3991(98)00116-5

Berinsky, A. J., Huber, G. A., \& Lenz, G. S. (2012). Evaluating online labor markets for 
experimental research: Amazon.com's Mechanical Turk. Political Analysis, 20(3), 351368. https://doi.org/10.1093/pan/mpr057

Berkman, N. D., Sheridan, S. L., Donahue, K. E., Halpern, D. J., \& Crotty, K. (2011). Low health literacy and health outcomes: An updated systematic review. Annals of Internal Medicine, 155(2), 97-107. https://doi.org/10.7326/0003-4819-155-2-201107190-00005

Boerwinkel, D. J., Yarden, A., \& Waarlo, A. J. (2017). Reaching a consensus on the definition of genetic literacy that is required from a twenty-first-century citizen. Science \& Education, 26(10), 1087-1114. https://doi.org/10.1007/s11191-017-9934-y

Bowling, B. V., Acra, E. E., Wang, L., Myers, M. F., Dean, G. E., Markle, G. C., Moskalik, C. L., \& Huether, C. A. (2008). Development and evaluation of a genetics literacy assessment instrument for undergraduates. Genetics, 178(1), 15-22. https://doi.org/10.1534/genetics.107.079533

Buhrmester, M., Kwang, T., \& Gosling, S. D. (2011). Amazon's Mechanical Turk: A new source of inexpensive, yet high-quality, data? Perspectives on Psychological Science, 6(1), 3-5. https://doi.org/10.1177/1745691610393980

Campbell, D. T., \& Fiske, D. W. (1959). Convergent and discriminant validation by the multitrait-multimethod matrix. Psychological Bulletin, 56(2), 81-105. https://doi.org/10.1037/h0046016

Carere, D. A., Kraft, P., Kaphingst, K. A., Roberts, J. S., \& Green, R. C. (2016). Consumers report lower confidence in their genetics knowledge following direct-to-consumer personal genomic testing. Genetics in Medicine, 18(1), 65-72. https://doi.org/10.1038/gim.2015.34 
Chakravarti A. (2011). Genomic contributions to Mendelian disease. Genome Research, 21(5), 643-644. https://doi.org/10.1101/gr.123554.111

Chapman, R., Likhanov, M., Selita, F., Zakharov, I., Smith-Woolley, E., \& Kovas, Y. (2017). Genetic Literacy and Attitudes Survey (iGLAS): International population-wide assessment instrument. The European Proceedings of Social \& Behavioural Sciences, 33(6), 45-66. https://doi.org/10.15405/epsbs.2017.12.6

Cheung, J. H., Burns, D. K., Sinclair, R. R., \& Sliter, M. (2017). Amazon Mechanical Turk in organizational psychology: An evaluation and practical recommendations. Journal of Business and Psychology, 32(4), 347-361. https://doi.org/10.1007/s10869-016-9458-5

Chinn, D., \& McCarthy, C. (2013). All Aspects of Health Literacy Scale (AAHLS): Developing a tool to measure functional, communicative and critical health literacy in primary healthcare settings. Patient Education and Counseling, 90(2), 247-253. https://doi.org/10.1016/j.pec.2012.10.019

Davis, T. C., Crouch, M. A., Long, S. W., Jackson, R. H., Bates, P., George, R. B., \& Bairnsfather, L. E. (1991). Rapid assessment of literacy levels of adult primary care patients. Family Medicine, 23(6), 433-435. https://pubmed.ncbi.nlm.nih.gov/1936717/

Duell, P., Wright, D., Renzaho, A. M., \& Bhattacharya, D. (2015). Optimal health literacy measurement for the clinical setting: A systematic review. Patient Education and Counseling, 98(11), 1295-1307. https://doi.org/10.1016/j.pec.2015.04.003

Dumenci, L., Matsuyama, R. K., Kuhn, L., Perera, R. A., \& Siminoff, L. A. (2013). On the validity of the shortened Rapid Estimate of Adult Literacy in Medicine (REALM) scale as a measure of health literacy. Communication Methods and Measures, 7(2), 134-143. https://doi.org/10.1080/19312458.2013.789839 
Duquette, D. (2019). Implementation of public health genomics and applications to public health dentistry. Journal of Public Health Dentistry. https://doi.org/10.1111/jphd.12307

Erby, L. H., Roter, D., Larson, S., \& Cho, J. (2008). The rapid estimate of adult literacy in genetics (REAL-G): A means to assess literacy deficits in the context of genetics. American Journal of Medical Genetics Part A, 146(2), 174-181. https://doi.org/10.1002/ajmg.a.32068

Faul, F., Erdfelder, E., Lang, A. G., \& Buchner, A. (2007). G* Power 3: A flexible statistical power analysis program for the social, behavioral, and biomedical sciences. Behavior Research Methods, 39(2), 175-191. https://doi.org/10.3758/BF03193146

Fitzgerald-Butt, S. M., Bodine, A., Fry, K. M., Ash, J., Zaidi, A. N., Garg, V., Gerhardt, C. A., \& McBride, K. L. (2016). Measuring genetic knowledge: A brief survey instrument for adolescents and adults. Clinical Genetics, 89(2), 235-243.

https://doi.org/10.1111/cge.12618

Flesch, R. (1948). A new readability yardstick. Journal of Applied Psychology, 32(3), 221-233. https://doi.org/10.1037/h0057532

Furr, L. A., \& Kelly, S. E. (1999). The Genetic Knowledge Index: Developing a standard measure of genetic knowledge. Genetic Testing, 3(2), 193-199. https://doi.org/10.1089/gte.1999.3.193

Geddes J. (2014, December 5). Best anti-aging skin care product ever? Geneu high-tech serum uses microchip to reduce wrinkles. Tech Times. https://www.techtimes.com/articles/21635/20141205/best-anti-aging-skin-cream-productever-geneu-high-tech-serum-uses-microchip-to-reduce-wrinkles.htm 
Green M. J., Biesecker B. B., McInerney A. M., Mauger D., Fost N. (2001). An interactive computer program can effectively educate patients about genetic testing for breast cancer susceptibility. American Journal of Medical Genetics, 103(1), 16-23. https://doi.org/10.1002/ajmg.1500

Hogarth, S., Javitt, G., \& Melzer, D. (2008). The current landscape for direct-to-consumer genetic testing: Legal, ethical, and policy issues. Annual Review of Genomics and Human Genetics, 9, 161-182. https://doi.org/10.1146/annurev.genom.9.081307.164319

Hooker, G. W., Peay, H., Erby, L., Bayless, T., Biesecker, B. B., \& Roter, D. L. (2014). Genetic literacy and patient perceptions of IBD testing utility and disease control: A randomized vignette study of genetic testing. Inflammatory Bowel Diseases, 20(5), 901-908. https://doi.org/10.1097/MIB.0000000000000021

Institute of Medicine. (2004). Health literacy: A prescription to end confusion. Washington DC: The National Academies Press. https://doi.org/10.17226/10883

Jackson, M., Marks, L., May, G., \& Wilson, J. B. (2018). The genetic basis of disease. Essays in Biochemistry, 62(5), 643-723. https://doi.org/10.1042/EBC20170053

Jallinoja, P., \& Aro, A. R. (1999). Knowledge about genes and heredity among Finns. New Genetics and Society, 18(1), 101-110. https://doi.org/10.1080/14636779908656892

Jalonick M. C. (2015, May 14). USDA develops new government label for GMO-free products. The Washington Post. https://www.washingtonpost.com/national/health-science/usdadevelops-certification-labeling-for-gmo-free-foods/2015/05/14/61822a1c-fa54-11e49ef4-1bb7ce3b3fb7_story.html 
Jones, K., Brennan, D., Parker, E., \& Jamieson, L. (2015). Development of a short-form health literacy dental scale (HeLD-14). Community Dentistry and Oral Epidemiology, 43(2), 143-151. https://doi.org/10.1111/cdoe.12133

Jordan, J. E., Buchbinder, R., Briggs, A. M., Elsworth, G. R., Busija, L., Batterham, R., \& Osborne, R. H. (2013). The Health Literacy Management Scale (HeLMS): A measure of an individual's capacity to seek, understand and use health information within the healthcare setting. Patient Education and Counseling, 91(2), 228-235. https://doi.org/10.1016/j.pec.2013.01.013

Kaphingst, K. A., Facio, F. M., Cheng, M. R., Brooks, S., Eidem, H., Linn, A., Biesecker, B. B., \& Biesecker, L. G. (2012). Effects of informed consent for individual genome sequencing on relevant knowledge. Clinical Genetics, 82(5), 408-415. https://doi.org/10.1111/j.1399-0004.2012.01909.x

Kaphingst, K. A., Blanchard, M., Milam, L., Pokharel, M., Elrick, A., \& Goodman, M. S. (2016). Relationships between health literacy and genomics-related knowledge, selfefficacy, perceived importance, and communication in a medically underserved population. Journal of Health Communication, 21(sup1), 58-68. https://doi.org/10.1080/10810730.2016.1144661

Kenneth, G. T., \& William, C. (1981). The development and validation of a group test of logical thinking. Educational and Psychological Measurement, 41(2), 413-423.

\section{https://doi.org/10.1177/001316448104100220}

Kornman, K. S., \& Duff, G. W. (2012). Personalized medicine: Will dentistry ride the wave or watch from the beach?. Journal of Dental Research, 91(7_suppl), S8-S11. https://doi.org/10.1177/0022034512449171 
Kutner, M., Greenberg, E., Jin, Y., Boyle, B., Hsu, Y. C., \& Dunleavy, E. (2007). Literacy in everyday life: Results from the 2003 National Assessment of Adult Literacy. National Center for Education Statistics. https://files.eric.ed.gov/fulltext/ED495996.pdf

Lachance, C. R., Erby, L. A., Ford, B. M., Allen, V. C., \& Kaphingst, K. A. (2010). Informational content, literacy demands, and usability of websites offering health-related genetic tests directly to consumers. Genetics in Medicine, 12(5), 304-312. https://doi.org/10.1097/GIM.0b013e3181dbd8b2

Lambert, S. A., Abraham, G., \& Inouye, M. (2019). Towards clinical utility of polygenic risk scores. Human Molecular Genetics, 28(R2), R133-R142. https://doi.org/10.1093/hmg/ddz187

Langer, M. M., Roche, M. I., Brewer, N. T., Berg, J. S., Khan, C. M., Leos, C., Moore, E., Brown, M., \& Rini, C. (2017). Development and validation of a genomic knowledge scale to advance informed decision-making research in genomic sequencing. MDM Policy \& Practice, 2(1), 2381468317692582. https://doi.org/10.1177/2381468317692582

LePoire, E., Basu, B., Walker, L., \& Bowen, D. J. (2019). What do people think about genetics? A systematic review. Journal of Community Genetics, 10(2), 171-187. https://doi.org/10.1007/s12687-018-0394-0

Litman, L., Robinson, J., \& Rosenzweig, C. (2020). Sampling mechanical turk workers. In L. Litman \& J. Robinson (Eds.), Conducting online research on Amazon Mechanical Turk and beyond. Sage Publications, Inc.

McNeil, D. W., Crout, R. J., \& Marazita, M. L. (2012). Oral health. In R. L. Ludke, \& P. J. Obermiller (Eds.), Appalachian health and well-being (pp. 275-294). University Press of Kentucky. 
Milo Rasouly, H., Cuneo, N., Marasa, M., DeMaria, N., Chatterjee, D., Thompson, J. J., ... \& Gharavi, A. G. (2021). GeneLiFT: A novel test to facilitate rapid screening of genetic literacy in a diverse population undergoing genetic testing. Journal of Genetic Counseling, 30(3), 742-754. https://doi.org/10.1002/jgc4.1364

Nutbeam, D. (1998). Health promotion glossary. Health Promotion International, 13(4), 349364. https://doi.org/10.1093/heapro/13.4.349

Nutbeam, D. (2000). Health literacy as a public health goal: A challenge for contemporary health education and communication strategies into the 21st century. Health Promotion International, 15(3), 259-267. https://doi.org/10.1093/heapro/15.3.259

Osborne, R. H., Batterham, R. W., Elsworth, G. R., Hawkins, M., \& Buchbinder, R. (2013). The grounded psychometric development and initial validation of the Health Literacy Questionnaire (HLQ). BMC Public Health, 13(1), 658. https://doi.org/10.1186/1471$\underline{2458-13-658}$

Qualtrics. (2021). Qualtrics [Computer software]. Provo, Utah, USA. https://www.qualtrics.com Rafiq, M., Ianuale, C., Ricciardi, W., \& Boccia, S. (2015). Direct-to-consumer genetic testing: A systematic review of European guidelines, recommendations, and position statements. Genetic Testing and Molecular Biomarkers, 19(10), 535-547. https://doi.org/10.1089/gtmb.2015.0051

Rawson, K. A., Gunstad, J., Hughes, J., Spitznagel, M. B., Potter, V., Waechter, D., \& Rosneck, J. (2010). The METER: A brief, self-administered measure of health literacy. Journal of General Internal Medicine, 25(1), 67-71. https://doi.org/10.1007/s11606-009-1158-7 
Richman A. R., Tzeng J. P., Carey L. A., Rete`l V. P., \& Brewer N. T. (2011). Knowledge of genomic testing among early-stage breast cancer patients. Psycho-Oncology, 20(1), 2835. https://doi.org/10.1002/pon.1699

Roberts, J. S., Gornick, M. C., Carere, D. A., Uhlmann, W. R., Ruffin, M. T., \& Green, R. C. (2017). Direct-to-consumer genetic testing: user motivations, decision making, and perceived utility of results. Public Health Genomics, 20(1), 36-45. https://doi.org/10.1159/000455006

Sanderson, S. C., Loe, B. S., Freeman, M., Gabriel, C., Stevenson, D. C., Gibbons, C., Chitty, L., \& Lewis, C. (2018). Development of the Knowledge of Genome Sequencing (KOGS) questionnaire. Patient Education and Counseling, 101(11), 1966-1972. https://doi.org/10.1016/j.pec.2018.07.011

Scuffham, T. M., McInerny-Leo, A., Ng, S. K., \& Mellick, G. (2014). Knowledge and attitudes towards genetic testing in those affected with Parkinson's disease. Journal of Community Genetics, 5(2), 167-177. https://doi.org/10.1007/s12687-013-0168-7

Stark, Z., Dolman, L., Manolio, T. A., Ozenberger, B., Hill, S. L., Caulfied, M. J., Boughtwood, T., Braithwaite, J., Goodhand, P., Birney, E., \& North, K. N. (2019). Integrating genomics into healthcare: A global responsibility. The American Journal of Human Genetics, 104(1), 13-20. https://doi.org/10.1016/j.ajhg.2018.11.014

Torkamani, A., Wineinger, N. E., \& Topol, E. J. (2018). The personal and clinical utility of polygenic risk scores. Nature Reviews Genetics, 19(9), 581-590. https://doi.org/10.1038/s41576-018-0018-x 
Weiss, B. D., Mays, M. Z., Martz, W., Castro, K. M., DeWalt, D. A., Pignone, M. P., Mockbee, J., \& Hale, F. A. (2005). Quick assessment of literacy in primary care: the newest vital sign. The Annals of Family Medicine, 3(6), 514-522. https://doi.org/10.1370/afm.405

Wilkinson, G. S., \& Robertson, G. J. (2006). Wide range achievement test 4 (WRAT4). Lutz, FL: Psychological Assessment Resources.

World Health Organization. (1948). World health organization constitution. Basic Documents, 1, 22.

Zhang, X. H., Qiu, L. Q., Ye, Y. H., \& Xu, J. (2017). Chromosomal abnormalities: Subgroup analysis by maternal age and perinatal features in zhejiang province of China, 20112015. Italian Journal of Pediatrics, 43(1), 1-6. https://doi.org/10.1186/s13052-017-0363y 


\section{Tables}

\section{Table 1}

Genetic Literacy Instruments

\begin{tabular}{|c|c|c|c|c|c|}
\hline Instrument & Author & Item type & Sample & Reliability & Validity \\
\hline $\begin{array}{l}\text { Knowledge of } \\
\text { Genes and } \\
\text { Heredity } \\
\text { Measure }\end{array}$ & $\begin{array}{l}\text { Jallinoja } \\
\text { \& Aro, } \\
1999\end{array}$ & $\begin{array}{l}16 \text { true/false } \\
\text { items }\end{array}$ & $\begin{array}{l}\text { Representative } \\
\text { sample of } \\
\text { Finnish } \\
\text { population } \\
(n=1216)\end{array}$ & $\begin{array}{l}\text { Internal } \\
\text { consistency: } \\
\text { Cronbach's } \\
\text { alpha }=0.86\end{array}$ & - \\
\hline $\begin{array}{l}\text { Genetic } \\
\text { Knowledge } \\
\text { Index (GKI) }\end{array}$ & $\begin{array}{l}\text { Furr \& } \\
\text { Kelly, } \\
1999\end{array}$ & $\begin{array}{l}5 \text { true/false } \\
\text { items }\end{array}$ & $\begin{array}{l}\text { Convenience } \\
\text { sample } \\
(n=330)\end{array}$ & $\begin{array}{l}\text { Internal } \\
\text { consistency: } \\
\text { Cronbach's } \\
\text { alpha }=0.74\end{array}$ & $\begin{array}{l}\text { Educational } \\
\text { attainment } \\
r=0.28 ; \\
\text { Attitudes } \\
\text { toward genetic } \\
\text { discrimination } \\
r=-0.33\end{array}$ \\
\hline $\begin{array}{l}\text { Genetics } \\
\text { Literacy } \\
\text { Assessment } \\
\text { Instrument } \\
\text { (GLAI) }\end{array}$ & $\begin{array}{l}\text { Bowling } \\
\text { et al., } \\
2008\end{array}$ & $\begin{array}{l}31 \text { multiple- } \\
\text { choice items }\end{array}$ & $\begin{array}{l}\text { Convenience } \\
\text { sample of } \\
\text { undergraduates } \\
\text { and graduate } \\
\text { students } \\
(n=525)\end{array}$ & $\begin{array}{l}\text { Internal } \\
\text { consistency: } \\
\text { Cronbach's } \\
\text { alpha }=0.99 \text {; } \\
\text { Test-retest: } \\
r=0.68\end{array}$ & - \\
\hline $\begin{array}{l}\text { Rapid Estimate } \\
\text { of Adult } \\
\text { Literacy in } \\
\text { Genetic (REAL- } \\
\text { G) }\end{array}$ & $\begin{array}{l}\text { Erby et al., } \\
2008\end{array}$ & $\begin{array}{l}63 \\
\text { pronunciation- } \\
\text { based items ( } 8 \\
\text { items on } \\
\text { shortened } \\
\text { version) }\end{array}$ & $\begin{array}{l}\text { Convenience } \\
\text { sample } \\
(n=203)\end{array}$ & - & $\begin{array}{l}\text { REALM } \\
r=0.83\end{array}$ \\
\hline $\begin{array}{l}\text { Genetic Literacy } \\
\text { and } \\
\text { Comprehension } \\
\text { Measure } \\
\text { (GLAC) }\end{array}$ & $\begin{array}{l}\text { Hooker et } \\
\text { al., } 2014\end{array}$ & $\begin{array}{l}8 \text { items ranked } \\
\text { on 7-point } \\
\text { familiarity } \\
\text { scale }\end{array}$ & $\begin{array}{l}\text { Convenience } \\
\text { clinical sample } \\
(n=257)\end{array}$ & $\begin{array}{l}\text { Internal } \\
\text { consistency: } \\
\text { Cronbach's } \\
\text { alpha }=0.95\end{array}$ & - \\
\hline $\begin{array}{l}\text { Genome } \\
\text { Sequencing } \\
\text { Knowledge Test }\end{array}$ & $\begin{array}{l}\text { Kaphingst } \\
\text { et al., } \\
2012\end{array}$ & $\begin{array}{l}11 \text { true/false } \\
\text { items on a } 5- \\
\text { point Likert } \\
\text { scale }\end{array}$ & $\begin{array}{l}\text { Convenience } \\
\text { clinical sample } \\
(n=311)\end{array}$ & $\begin{array}{l}\text { Internal } \\
\text { consistency: } \\
\text { Cronbach's } \\
\text { alpha = } 0.80 \\
\text { (Limitation } \\
\text { subscale); }\end{array}$ & - \\
\hline
\end{tabular}




\begin{tabular}{|c|c|c|c|c|c|}
\hline & & & & $\begin{array}{l}\text { Cronbach's } \\
\text { alpha }=0.70 \\
\text { (Benefits } \\
\text { subscale) }\end{array}$ & \\
\hline $\begin{array}{l}\text { Genetic } \\
\text { Knowledge } \\
\text { Survey }\end{array}$ & $\begin{array}{l}\text { Fitzgerald- } \\
\text { Butt et al., } \\
2016\end{array}$ & $\begin{array}{l}18 \text { true/false } \\
\text { items }\end{array}$ & $\begin{array}{l}\text { Convenience } \\
\text { clinical sample } \\
(n=661)\end{array}$ & $\begin{array}{l}\text { Internal } \\
\text { consistency: } \\
\text { Cronbach's } \\
\text { alpha }=0.66 \\
\text { (Basic } \\
\text { subscale); } \\
\text { Cronbach's } \\
\text { alpha }=0.73 \\
\text { (Applied } \\
\text { subscale) }\end{array}$ & - \\
\hline $\begin{array}{l}\text { International } \\
\text { Genetic Literacy } \\
\text { and Attitudes } \\
\text { Survey (iGLAS) }\end{array}$ & $\begin{array}{l}\text { Chapman } \\
\text { et al., } \\
2017\end{array}$ & $\begin{array}{l}20 \text { multiple- } \\
\text { choice items }\end{array}$ & $\begin{array}{l}\text { Convenience } \\
\text { online sample } \\
(n>5,000)\end{array}$ & $\begin{array}{l}\text { Test-retest: } \\
r=0.67\end{array}$ & - \\
\hline $\begin{array}{l}\text { University of } \\
\text { North Carolina } \\
\text { Genomic } \\
\text { Knowledge } \\
\text { Scale (UNC- } \\
\text { GKS) }\end{array}$ & $\begin{array}{l}\text { Langer et } \\
\text { al., } 2017\end{array}$ & $\begin{array}{l}19 \\
\text { true/false/don't } \\
\text { know items }\end{array}$ & $\begin{array}{l}\text { Convenience } \\
\text { clinical sample } \\
(n=418)\end{array}$ & $\begin{array}{l}\text { Internal } \\
\text { consistency: } \\
\text { Cronbach's } \\
\text { alpha }=0.86\end{array}$ & $\begin{array}{l}\text { REAL-G } \\
r=0.46 ; \\
\text { REALM } \\
r=0.40 ; \\
\text { Subjective } \\
\text { numeracy } \\
r=0.43 ; \\
\text { Objective } \\
\text { numeracy } \\
r=0.41\end{array}$ \\
\hline $\begin{array}{l}\text { Knowledge of } \\
\text { Genome } \\
\text { Sequencing } \\
\text { (KOGS) }\end{array}$ & $\begin{array}{l}\text { Sanderson } \\
\text { et al., } \\
2018\end{array}$ & $\begin{array}{l}9 \\
\text { true/false/don't } \\
\text { know }\end{array}$ & $\begin{array}{l}\text { Convenience } \\
\text { sample } \\
(n=267)\end{array}$ & $\begin{array}{l}\text { Internal } \\
\text { consistency: } \\
\text { Cronbach's } \\
\text { alpha }=0.79\end{array}$ & - \\
\hline $\begin{array}{l}\text { Genetic Literacy } \\
\text { Fast Test } \\
(\text { GeneLiFT) }\end{array}$ & $\begin{array}{l}\text { Milo } \\
\text { Rasouly et } \\
\text { al., } 2021\end{array}$ & $\begin{array}{l}51 \text { vocabulary } \\
\text { recognition } \\
\text { items }\end{array}$ & $\begin{array}{l}\text { Convenience } \\
\text { clinical sample } \\
(n=724)\end{array}$ & - & $\begin{array}{l}\text { Significant } \\
\text { associations } \\
\text { with genetic } \\
\text { knowledge, } \\
\text { health literacy, } \\
\text { numeracy, and } \\
\text { education }\end{array}$ \\
\hline
\end{tabular}


Table 2

Sample Characteristics

\begin{tabular}{|c|c|c|}
\hline Characteristic & $n /$ Mean & $\% / S D$ \\
\hline Total $N$ & 809 & \\
\hline \multicolumn{3}{|l|}{ Gender } \\
\hline Male & 252 & $31.2 \%$ \\
\hline Female & 545 & $67.5 \%$ \\
\hline Other & 11 & $1.4 \%$ \\
\hline Age & 42.5 & 14.2 \\
\hline \multicolumn{3}{|l|}{ Race } \\
\hline White & 659 & $81.5 \%$ \\
\hline Black or African American & 74 & $9.1 \%$ \\
\hline American Indian or Alaskan Native & 6 & $0.7 \%$ \\
\hline Asian American & 28 & $3.5 \%$ \\
\hline Multiracial & 13 & $1.6 \%$ \\
\hline Other & 21 & $2.6 \%$ \\
\hline \multicolumn{3}{|l|}{ Ethnicity } \\
\hline Non-Hispanic & 746 & $92.2 \%$ \\
\hline Hispanic & 60 & $7.4 \%$ \\
\hline Other & 3 & $0.4 \%$ \\
\hline \multicolumn{3}{|l|}{ Children } \\
\hline Has children & 432 & $53.5 \%$ \\
\hline Does not have children & 376 & $46.5 \%$ \\
\hline \multicolumn{3}{|l|}{ Grandchildren } \\
\hline Has grandchildren & 114 & $14.1 \%$ \\
\hline Does not have children & 694 & $85.9 \%$ \\
\hline \multicolumn{3}{|l|}{ Household Income } \\
\hline$\$ 1,000-\$ 1,999$ & 15 & $1.9 \%$ \\
\hline$\$ 2,000-\$ 3,999$ & 16 & $2.0 \%$ \\
\hline$\$ 4,000-\$ 5,999$ & 13 & $1.6 \%$ \\
\hline$\$ 6,000-\$ 7,999$ & 9 & $1.1 \%$ \\
\hline$\$ 8,000-\$ 9,999$ & 12 & $1.5 \%$ \\
\hline$\$ 10,000-\$ 14,999$ & 39 & $4.8 \%$ \\
\hline$\$ 15,000-\$ 24,999$ & 74 & $9.2 \%$ \\
\hline$\$ 25,000-\$ 34,999$ & 96 & $11.9 \%$ \\
\hline$\$ 35,000-\$ 49,999$ & 124 & $15.3 \%$ \\
\hline$\$ 50,000-\$ 74,999$ & 155 & $19.2 \%$ \\
\hline$\$ 75,000-\$ 99,999$ & 103 & $12.7 \%$ \\
\hline$\$ 100,000-\$ 149,999$ & 98 & $12.1 \%$ \\
\hline
\end{tabular}


$\$ 150,000-\$ 199,999$

$31 \quad 3.8 \%$

$\$ 200,000$ or more

$23 \quad 2.8 \%$

Employment Status

Employed - full time

$467 \quad 57.7 \%$

Employed - part time

$140 \quad 17.3 \%$

Unemployed - looking for work

$88 \quad 10.9 \%$

Unemployed - disabled, unable to work

$51 \quad 6.3 \%$

Retired

$63 \quad 7.8 \%$

Education

Some high school, no diploma

$11 \quad 1.4 \%$

High school graduate, diploma, or GED

$81 \quad 10.0 \%$

Some college credit, no degree

$175 \quad 21.6 \%$

Trade/technical/vocational training

$36 \quad 4.4 \%$

Associate degree

$99 \quad 12.2 \%$

Bachelor's degree

$247 \quad 30.5 \%$

Graduate/professional, no degree

$43 \quad 5.3 \%$

Graduate/professional, completed, diploma

$117 \quad 14.5 \%$

Political Orientation $(0=$ strongly liberal; $10=$ strongly conservative $)$

Economically

$4.7 \quad 3.2$

Socially

$4.1 \quad 3.2$

Religion

Agnostic

$133 \quad 16.5 \%$

Atheist

$90 \quad 11.1 \%$

No religion

$77 \quad 9.5 \%$

Christian

$438 \quad 54.2 \%$

Buddhist

$16 \quad 2.0 \%$

Hindu

$3 \quad 0.4 \%$

Jewish

$8 \quad 1.0 \%$

Muslim

9

$1.1 \%$

Other

34

$4.2 \%$

Religiosity $(0=$ not at all religious; $10=$ extremely religious $)$

4.3

3.7 
Table 3

Background with Genetics and Genetic Testing

\begin{tabular}{|c|c|c|}
\hline Variable & $n /$ Mean & $\% / S D$ \\
\hline \multicolumn{3}{|l|}{ Genetics Education } \\
\hline Studied genetics as a part of a school curriculum & 266 & $32.9 \%$ \\
\hline Studied genetics as a part of university degree & 128 & $15.8 \%$ \\
\hline Worked in the field of genetics & 18 & $2.2 \%$ \\
\hline Studied genetics myself & 152 & $18.8 \%$ \\
\hline Currently studying genetics & 11 & $1.4 \%$ \\
\hline Follow genetics topics on social media & 82 & $10.1 \%$ \\
\hline Never studied genetics & 399 & $49.3 \%$ \\
\hline Have no interest in the topic of genetics & 74 & $9.1 \%$ \\
\hline \multicolumn{3}{|l|}{ Self-reported Genetic Knowledge $(0=$ not at all confident; } \\
\hline \multicolumn{3}{|l|}{ Genetic disorder (Self) } \\
\hline Yes & 92 & $11.4 \%$ \\
\hline No & 716 & $88.6 \%$ \\
\hline Genetic disorder (Family Members) & & $0.0 \%$ \\
\hline Yes & 164 & $20.3 \%$ \\
\hline No & 644 & $79.7 \%$ \\
\hline \multicolumn{3}{|l|}{ Previous Genetic Testing (Self) } \\
\hline Yes & 184 & $23.3 \%$ \\
\hline No & 607 & $76.7 \%$ \\
\hline \multicolumn{3}{|l|}{ Type of Genetic Testing (Self) } \\
\hline Medical diagnosis or risk of disorder & 63 & $34.2 \%$ \\
\hline Health-related information & 65 & $35.3 \%$ \\
\hline Ancestry, heritage, or genealogy information & 144 & $78.3 \%$ \\
\hline Other & 8 & $4.3 \%$ \\
\hline \multicolumn{3}{|l|}{ Previous Genetic Testing (Family) } \\
\hline Yes & 238 & $34.8 \%$ \\
\hline No & 446 & $65.2 \%$ \\
\hline \multicolumn{3}{|l|}{ Type of Genetic Testing (Family) } \\
\hline Medical diagnosis or risk of disorder & 56 & $23.5 \%$ \\
\hline Health-related information & 57 & $23.9 \%$ \\
\hline Ancestry, heritage, or genealogy information & 199 & $83.6 \%$ \\
\hline Other & 3 & $1.3 \%$ \\
\hline I don't know & 6 & $2.5 \%$ \\
\hline
\end{tabular}




\section{Table 4}

Test Descriptive Statistics and Psychometric Properties of Genetic Literacy Measures

\begin{tabular}{|c|c|c|c|c|c|c|c|c|}
\hline Scale & Mean & $S D$ & Min & Max & $\begin{array}{l}\text { Scale } \\
\text { Range }\end{array}$ & $\begin{array}{c}\text { Cronbach's } \\
\text { Alpha }\end{array}$ & $\begin{array}{c}\text { Flesch- } \\
\text { Kincaid Grade } \\
\text { Level }\end{array}$ & $\begin{array}{c}\text { Flesch } \\
\text { Reading } \\
\text { Ease }\end{array}$ \\
\hline \multicolumn{9}{|l|}{ Genetic } \\
\hline Knowledge Survey & 13.9 & 3.5 & 0 & 18 & $0-18$ & 0.82 & 7.0 & 61.3 \\
\hline UNC-GKS & 13.3 & 4.0 & 0 & 19 & $0-19$ & 0.83 & 8.6 & 57.2 \\
\hline iGLAS-GK & 12.1 & 3.2 & 4 & 20 & $0-20$ & 0.67 & 6.5 & 66.8 \\
\hline HeLD & 97.9 & 18.8 & 10 & 116 & $0-116$ & - & - & - \\
\hline sTOFHLA & 34.6 & 3.6 & 8 & 36 & $0-36$ & - & - & - \\
\hline TOLT & 3.4 & 2.7 & 0 & 10 & $0-10$ & - & - & - \\
\hline
\end{tabular}

Note. $N=809$. UNC-GKS $=$ University of North Carolina Genomic knowledge Scale; iGLAS-GK = International Genetic Literacy and Attitudes Survey-Genetic Knowledge Scale; HeLD = Health Literacy in Dentistry Scale Questionnaire; sTOFHLA = Test of Functional Health Literacy in Adults Shortened; TOLT $=$ Test of Logical Thinking. 
Table 5

Genetic Knowledge Survey Item Analysis

\begin{tabular}{lcccc}
\hline & \multicolumn{2}{c}{ Correct } & \multicolumn{2}{c}{ I Don't Know } \\
\hline & $n$ & $\%$ & $n$ & $\%$ \\
\hline Item 1 & 755 & $93.3 \%$ & 30 & $3.7 \%$ \\
Item 2 & 743 & $91.8 \%$ & 37 & $4.5 \%$ \\
Item 3 & 743 & $91.8 \%$ & 39 & $4.8 \%$ \\
Item 4 & 738 & $91.2 \%$ & 42 & $5.2 \%$ \\
Item 5 & 655 & $81.0 \%$ & 118 & $14.5 \%$ \\
Item 6 & 701 & $86.7 \%$ & 71 & $8.7 \%$ \\
Item 7 & 573 & $70.8 \%$ & 170 & $20.9 \%$ \\
Item 8 & 644 & $79.6 \%$ & 111 & $13.6 \%$ \\
Item 9 & 658 & $81.3 \%$ & 91 & $11.2 \%$ \\
Item 10 & 642 & $79.4 \%$ & 121 & $14.8 \%$ \\
Item 11 & 559 & $69.1 \%$ & 194 & $23.8 \%$ \\
Item 12 & 544 & $67.2 \%$ & 202 & $24.8 \%$ \\
Item 13 & 754 & $93.2 \%$ & 31 & $3.8 \%$ \\
Item 14 & 606 & $74.9 \%$ & 135 & $16.6 \%$ \\
Item 15 & 408 & $50.4 \%$ & 210 & $25.8 \%$ \\
Item 16 & 476 & $58.8 \%$ & 192 & $23.6 \%$ \\
Item 17 & 321 & $39.7 \%$ & 197 & $24.2 \%$ \\
Item 18 & 714 & $88.3 \%$ & 70 & $8.6 \%$ \\
\hline
\end{tabular}

Note. $N=809$. 
Table 6

UNC-GKS Item Analysis

\begin{tabular}{lcccc}
\hline & \multicolumn{2}{c}{ Correct } & \multicolumn{2}{c}{ I Don't Know } \\
\hline & $n$ & $\%$ & $n$ & $\%$ \\
\hline Item 1 & 667 & $82.4 \%$ & 84 & $10.3 \%$ \\
Item 2 & 629 & $77.8 \%$ & 130 & $16.0 \%$ \\
Item 3 & 663 & $82.0 \%$ & 103 & $12.6 \%$ \\
Item 4 & 562 & $69.5 \%$ & 171 & $21.0 \%$ \\
Item 5 & 549 & $67.9 \%$ & 228 & $28.0 \%$ \\
Item 6 & 331 & $40.9 \%$ & 386 & $47.4 \%$ \\
Item 7 & 715 & $88.4 \%$ & 70 & $8.6 \%$ \\
Item 8 & 319 & $39.4 \%$ & 243 & $29.8 \%$ \\
Item 9 & 528 & $65.3 \%$ & 183 & $22.5 \%$ \\
Item 10 & 696 & $86.0 \%$ & 75 & $9.2 \%$ \\
Item 11 & 545 & $67.4 \%$ & 209 & $25.6 \%$ \\
Item 12 & 604 & $74.7 \%$ & 144 & $17.7 \%$ \\
Item 13 & 406 & $50.2 \%$ & 128 & $15.7 \%$ \\
Item 14 & 613 & $75.8 \%$ & 121 & $14.8 \%$ \\
Item 15 & 631 & $78.0 \%$ & 120 & $14.7 \%$ \\
Item 16 & 582 & $71.9 \%$ & 150 & $18.4 \%$ \\
Item 17 & 438 & $54.1 \%$ & 208 & $25.5 \%$ \\
Item 18 & 624 & $77.1 \%$ & 118 & $14.5 \%$ \\
Item 19 & 666 & $82.3 \%$ & 97 & $11.9 \%$ \\
\hline
\end{tabular}

Note. $N=809$. UNC-GKS = University of North Carolina -

Genomic Knowledge Scale 
Table 7

iGLAS-GK Item Analysis

\begin{tabular}{ccc}
\hline & \multicolumn{2}{c}{ Correct } \\
\hline & $n$ & $\%$ \\
\hline Item 1 & 518 & $64.0 \%$ \\
Item 2 & 568 & $70.2 \%$ \\
Item 3 & 373 & $46.1 \%$ \\
Item 4 & 483 & $59.7 \%$ \\
Item 5 & 706 & $87.3 \%$ \\
Item 6 & 166 & $20.5 \%$ \\
Item 7 & 470 & $58.1 \%$ \\
Item 8 & 693 & $85.7 \%$ \\
Item 9 & 355 & $43.9 \%$ \\
Item 10 & 349 & $43.1 \%$ \\
Item 11 & 507 & $62.7 \%$ \\
Item 12 & 584 & $72.2 \%$ \\
Item 13 & 214 & $26.5 \%$ \\
Item 14 & 530 & $65.5 \%$ \\
Item 15 & 701 & $86.7 \%$ \\
Item 16 & 427 & $52.8 \%$ \\
Item 17 & 712 & $88.0 \%$ \\
Item 18 & 643 & $79.5 \%$ \\
Item 19 & 654 & $80.8 \%$ \\
Item 20 & 118 & $14.6 \%$ \\
\hline Itete. $N=$
\end{tabular}

Note. $N=809$. iGLAS-GK =

International Genetic Literacy and

Attitudes Survey-Genetic Knowledge

Scale 
Table 8

Pearson Correlations for Genetic Literacy Tests and Other Instruments

\begin{tabular}{lcccccc}
\hline \multicolumn{1}{c}{ Scale } & 1 & 2 & 3 & 4 & 5 & 6 \\
\hline 1. Genetic Knowledge Survey & - & & & & & \\
2. UNC-GKS & $0.76^{*}$ & - & & & \\
3. iGLAS-GK & $0.49^{*}$ & $0.48^{*}$ & - & & \\
4. S-TOFHLA & $0.33^{*}$ & $0.29^{*}$ & $0.31^{*}$ & - & & \\
5. HeLD & $0.19 *$ & $0.16^{*}$ & $0.16^{*}$ & $0.38^{*}$ & - & \\
6. TOLT & $0.44^{*}$ & $0.44^{*}$ & $0.49^{*}$ & $0.27^{*}$ & $0.13^{*}$ & - \\
\hline
\end{tabular}

Note. $N=809$; UNC-GKS = University of North Carolina Genomic knowledge Scale; iGLAS-GK = International Genetic Literacy and Attitudes Survey-Genetic Knowledge Scale; HeLD = Health Literacy in Dentistry Scale Questionnaire; sTOFHLA = Test of Functional Health Literacy in Adults - Shortened; TOLT $=$ Test of Logical Thinking. $* p<.01$. 


\section{Appendix A}

\section{International Genetic Literacy and Attitudes Survey-Genetic Knowledge Scale}

1. What is a genome?
a. A sex chromosome
b. The entire sequence of an individual's DNA
c. All the genes in DNA
d. Gene expression

2. Which of the following 4 letter groups represent the base units of DNA?
a. GHPO
b. HTPR
c. CGTA
d. LFWE

3. How many copies of each gene do we have in each autosome cell?
a. 1 copy
b. 2 copies
c. 23 copies
d. 5 copies

4. People differ in the amount of DNA they share. How much of this differing DNA do siblings usually share?
a. $75 \%$
b. $50 \%$
c. $.01 \%$
d. $99.9 \%$

5. What is the main function of all genes?
a. Storing information for protein synthesis
b. To provide energy to the cell
c. To clear out waste from the cell
d. To repair damage to a cell

6. On average, how much of their total DNA is the same in two people selected at random?
a. Less than $50 \%$
b. $75 \%$
c. $90 \%$
d. More than $99 \%$

7. Genetic contribution to the risk for developing Schizophrenia comes from:
a. One gene
b. Many genes

8. In humans, DNA is packaged into how many pairs of chromosomes?
a. 23 pairs
b. 48 pairs
c. 10 pairs
d. 27 pairs

9. An Epigenetic change is:

a. A change in gene expression

b. A change of the genetic code itself 
c. A process by which human beings can consciously change their DNA

d. Gene splicing

10. Approximately how many genes does the human DNA code contain?
a. 2,000
b. 1 million
c. 3 billion
d. 20,000

11. Genetic contribution to the risk for developing Autism comes from:

a. One gene

b. Many genes

12. What are polymorphisms?

a. Building blocks of the DNA

b. Proteins found in the brain

c. Points of genetic variation

d. Deoxyribonucleic Acid

13. The DNA sequence in two different cells, for example a neuron and a heart cell, of one person, is:
a. Entirely different
b. About $50 \%$ the same
c. More than $90 \%$ the same
d. $100 \%$ identical

14. Non-coding DNA describes DNA that:

a. Is removed when passed from parent to offspring

b. Does not lead to the production of proteins

c. Is non-human DNA

d. In not composed of nucleotides

15. Can dog breeding be considered a form of gene engineering?

a. Yes

b. No

16. Which of the mentioned below is a method for gene editing?
a. ERP
b. CRISPR
c. CERN
d. PCR

17. Can we fully predict a person's behavior from examining their DNA sequence?

a. Yes

b. No

18. At present in many countries, new born infants are tested for certain genetic traits.
a. True
b. False

19. Some of the genes that relate to dyslexia also relate to ADHD.

a. True

b. False

20. If a report states that "insomnia is approximately $30 \%$ heritable" what would that mean?

a. If someone has insomnia this is approximately $30 \%$ due to their genes 
b. Approximately $30 \%$ of people will experience insomnia at some point in their lives

c. Genetic influences account for approximately $30 \%$ of the differences between people in insomnia

d. There is an approximately $30 \%$ chance that someone will pass insomnia onto their children 


\section{Appendix B}

\section{University of North Carolina Genomic Knowledge Scale}

1. Genes are made of DNA.

2. Genes affect health by influencing the proteins our bodies make.

3. All of a person's genetic information is called his or her genome.

4. A person's genes change completely every 7 years.

5. The DNA in a gene is made of four building blocks (A, C, T, and G).

6. Everyone has about 20,000 to 25,000 genes.

7. Gene variants can have positive effects, harmful effects, or no effects on health.

8. Most gene variants will affect a person's health.

9. Everyone who has a harmful gene variant will eventually have symptoms.

10. Some gene variants have a large effect on health while others have a small effect.

11. Some gene variants decrease the chance of developing a disorder.

12. Two unrelated people with the same genetic variant will always have the same symptoms.

13. Genetic disorders are always inherited from a parent.

14. If only one person in the family has a disorder it can't be genetic.

15. Everyone has a chance for having a child with a genetic disorder.

16. A girl inherits most of her genes from her mother while a boy inherits most of his genes from his father.

17. A mother and daughter who look alike are more genetically similar than a mother and daughter who do not look alike.

18. If a parent has a harmful gene variant, all of his or her children will inherit it.

19. If one of your parents has a gene variant, your brother and sister may also have it. 


\section{Appendix C}

\section{Genetic Knowledge Survey}

1. Some diseases are caused by genes, environment, and lifestyle.

2. A gene is a disease.

3. You can see a gene with the naked eye.

4. Healthy parents can have a child with an inherited disease.

5. A person with an altered (mutated) gene may be completely healthy

6. All serious diseases are inherited.

7. Genes are instruction for making proteins, which help the body grow and work properly.

8. The child of a person with an inherited disease will always have the same disease.

9. A gene is a piece of DNA.

10. Altered (mutated) genes can cause disease.

11. Genes are inside of cells.

12. A chromosome contains many genes.

13. Genes determine traits such as height, eye color, and facial appearance.

14. A person has thousands of genes.

15. Identical twins have different sets of genes.

16. Humans have 20 pairs of chromosomes.

17. Parents pass both copies of each chromosome to their child.

18. A genetic test can tell you if you have a higher chance to develop a specific disease. 


\section{Appendix D}

\section{Test of Functional Health Literacy in Adults - Shortened}

\section{$\underline{\text { Passage A }}$}

Your doctor has sent you to have a X-ray
a. stomach
b. diabetes
c. stiches
d. germs

You must have an stomach when you come for
a. asthma
b. empty
c. incest
d. anemia

a. is.

b. am.

c. if.

d. it.

The X-ray will
a. take
b. view
a. beds
c. talk
b. brains
d. look
c. hours
d. diets from 1 to 3 to do.

\section{THE DAY BEFORE THE X-RAY}

For supper have only a snack of fruit,
a. little
a. toes
b. broth
b. throat
c. attack
c. toast
d. nausea
d. thigh

After
a. minute,
b. midnight, a. easy
c. during,
b. ate
d. before,
c. drank
d. eat

, you must not or drink

anything at

until after you have the X-ray.
a. ill
a. are
b. all
b. has
c. each
c. had
d. any
d. was

THE DAY OF THE X-RAY 
Do not eat
a. appointment.
b. walk-in.
c. breakfast.
d. clinic.

Do not , even
a. drive,
a. heart.
b. drink,
b. breath.
c. dress,
c. water.
d. dose,
d. cancer.

If you have any , call the X-ray
a. answers,
b. exercises
b. Sprain
c. tracts,
d. questions,
a. Department
d. Toothache at 616-4500.

$\underline{\text { Passage B }}$

I agree to give correct information to if I can receive Medicaid.
a. hair
b. salt
c. see
d. ache

I___ to provide the county information to
a. agree
b. probe
c. send
d. gain

a. hide

b. risk

c. discharge

d. prove

statements given in this and hereby give permission to
a. emphysema
b. application
c. gallbladder
d. relationship

the ___ to get such proof. I
a. inflammation
a. investigate
b. religion
b. entertain
c. iron
c. understand

d. county

d. establish

that for Medacaid 
I must report any in my circumstances
a. changes
b. hormones
c. antacids
d. charges

within (10) days of becoming
a. three
a. award
b. one
b. aware
c. five
c. away
d. ten
d. await

I understand if I DO NOT like the
a. thus
b. this
c. that
d. than
a. marital
b. occupation
c. adult

d. decision

made on my

case, I have the to a fair hearing. I can
a. bright
b. left
c. wrong
d. right a a. request

b. refuse

c. fail

d. mend

hearing by writing or the county where I applied.
a. counting
b. reading
c. calling
d. smelling

If you TANF for any family
a. wash
b. want
c. cover
d. tape

a. member,

b. history,

c. weight,

d. seatbelt, , you will have to

a different application form.
a. relax
b. break
c. inhale
d. sign

a. Since

b. Whether,

c. However,

d. Because, , we will use 
the __ on this from to determine your
a. lung
b. date
c. meal
d. pelvic
a. hypoglycemia.
b. eligibility.
c. osteoporosis.
d. schizophrenia. 


\section{Appendix E}

\section{Health Literacy in Dentistry Scale (HeLD) Questionnaire}

1. Are you able to find the energy to manage your dental or oral health?

2. Are you able to pay attention to your dental or oral health needs?

3. Are you able to make time for things that are good for your dental or oral health?

4. Are you able to change your lifestyle to improve your dental or oral health?

5. Are you able to find dental health information in a language you understand?

6. Are you able to fill in dental forms (e.g., enrolment forms)?

7. Are you able to read written information (e.g., leaflets given to you by your dentist)?

8. Are you able to read dental or oral health information brochures left in dental clinics and waiting rooms?

9. Are you able to take family or a friend with you to a dental appointment?

10. Are you able to ask someone to go with you to a dental appointment?

11. Are you able to ask family or friends for help to understand dental or oral health information?

12. Are you able to pay to see a dentist?

13. Are you able to afford transport to dental clinics?

14. Are you able to pay for medication to manage your dental or oral health?

15. Do you know where a dentist can be contacted?

16. Do you know how to get a dentist's appointment?

17. Do you know what to do to get a dentist's appointment?

18. Do you know where you can see a dentist?

19. Are you able to ask a dentist questions to help you understand dental information?

20. Are you able to get the information you need when seeing a dentist?

21. Are you able to follow up with a dentist to understand information about your dental health?

22. Are you able to change to a different dentist to get better dental care?

23. Are you able to get a second opinion about your dental health from a dental health professional?

24. Are you able to look for a second opinion about your dental health from a dental health professional?

25. Are you able to use information from a dentist to make decisions about your dental health?

26. Are you able to discuss your dental or oral health with people other than a dentist?

27. Are you able to follow instructions that a dentist gives you?

28. Are you able to carry out instructions that a dentist gives you?

29. Are you able to use advice from a dentist to make decisions about your dental health? 


\section{Appendix F}

\section{Test of Logical Thinking}

Four large oranges are squeezed to make six glasses of juice. How much juice can be made from six oranges?
A. 7 glasses
B. 8 glasses
C. 9 glasses
D. 10 glasses
E. Other

A gardener bought a package containing 3 squash seeds and 3 bean seeds. If just one seed is selected from the package, what are the chances that it is a bean seed?
A. 1 out of 2
B. 1 out of 3
C. 1 out of 4
D. 1 out of 6
E. 4 out of 6 
Appendix G

\section{Validation Items}

Please select the number four for this question

$\begin{array}{lllll}1 & 2 & 3 & 4 & 5\end{array}$

What color are healthy teeth?

Red

Green

White

Black

What color are healthy gums?

Blue

Pink

Green

Silver

How many eyes are most people born with?

$\begin{array}{lllll}0 & 1 & 2 & 3 & 4\end{array}$ 